\title{
Overview of the WEEE Directive and Its Implementation in the Nordic Countries: National Realisations and Best Practices
}

\author{
Jenni Ylä-Mella, ${ }^{1}$ Kari Poikela, ${ }^{2}$ Ulla Lehtinen, ${ }^{3}$ Pia Tanskanen, ${ }^{4}$ Elisabeth Román, ${ }^{5}$ \\ Riitta L. Keiski, ${ }^{6}$ and Eva Pongrácz ${ }^{1}$ \\ ${ }^{1}$ Centre of Northern Environmental Technology, Thule Institute, University of Oulu, Oulu, Finland \\ ${ }^{2}$ Kemin Digipolis Oy, Kemi, Finland \\ ${ }^{3}$ Oulu Business School, University of Oulu, Oulu, Finland \\ ${ }^{4}$ Nokia Oyj, Espoo, Finland \\ ${ }^{5}$ Narvik University College, Narvik, Norway \\ ${ }^{6}$ Mass and Heat Transfer Process Engineering, Faculty of Technology, University of Oulu, Oulu, Finland
}

Correspondence should be addressed to Jenni Ylä-Mella; jenni.yla-mella@oulu.fi

Received 27 June 2014; Accepted 29 August 2014; Published 1 October 2014

Academic Editor: David Bolzonella

Copyright (C) 2014 Jenni Ylä-Mella et al. This is an open access article distributed under the Creative Commons Attribution License, which permits unrestricted use, distribution, and reproduction in any medium, provided the original work is properly cited.

\begin{abstract}
Electronic devices and mobile applications have become a part of everyday life. Fast technological progress and rapid product obsolescence have led to the rapid growth of waste electrical and electronic equipment (WEEE). Due to hazardous substances and also substantial amounts of valuable materials contained in electrical and electronic equipment, the European Union has implemented Directives related to WEEE, in order to reduce negative environmental and health impacts and to improve material recovery of valuable substances from WEEE. This paper provides an overview of the WEEE Directive and its implementation to national legislations in Finland, Sweden, and Norway and, further, describes how the nationwide WEEE recovery infrastructures in the Nordic countries have been built. The Nordic WEEE management systems are evaluated from the point of resource efficiency and best practices. Evidently, the WEEE management systems as established in the Nordic countries have advantages because the WEEE collection rates in 2012 were $12 \mathrm{~kg} /$ inhab./year, in Finland, $16 \mathrm{~kg} /$ inhab./year, in Sweden, and $27 \mathrm{~kg} /$ inhab./year, in Norway, despite their sparsely populated nature. The Swedish and Norwegian experiences, especially, with long history of WEEE recovery indicate that increasing consumer awareness leads to more environmentally sound behaviour and improves recovery efficiency.
\end{abstract}

\section{Introduction}

Production and use of electronic and electrical equipment have significantly increased during the last three decades; electronic devices and new applications have become a part of everyday life due to technological innovations. Fast technological progress, market expansion to developing countries, and product obsolescence have also led to the rapid growth of waste electrical and electronic equipment (WEEE). Due to burgeoning amounts and the complex mixture of materials and hazardous substances contained in electrical and electronic equipment (EEE), environmental and health impacts of WEEE have become increased concerns. While hazardous substances present in electronic equipment are not likely to be released during their regular use, they may pose hazards during waste treatment and disposal.
In the mid-1990s, more than 90\% of WEEE was landfilled, incinerated, or recovered without pretreatment and, therefore, a large proportion of hazardous substances found in the municipal waste stream came from WEEE. Already at that time, the amount of WEEE arising as waste was estimated to be around 6 million tonnes in the European Union (EU) and the growth rate of WEEE was expected to be $3-5 \%$ per year, which was about three times higher than the growth rate of municipal waste of EU [1]. In the late 1990s, some of the European countries such as Norway, Switzerland, the Netherlands, and Sweden began to prepare national legislations regarding WEEE management to prevent the environmental problems caused by uncontrolled disposal of WEEE. On the European Community level, a proposal $\{\mathrm{COM}$ (2000)347\} for two Directives was prepared and introduced, in June 2000 , in order to ensure the functioning of internal 
markets and adequately address the environmental problems associated with the treatment and disposal of WEEE.

Nowadays, WEEE is one of the largest growing waste streams globally. Development of new EEE applications have led to a situation where a number of materials formerly no more than scientific curiosities have an important role in electronics, resulting in a concern about their sufficiency and vulnerability of supply [2]. As recycling is regarded as a solution to substitute primary resources and decrease environmental loading, the efficient recovery of valuable materials from waste electronics is indispensable to ensure sustainable materials management. Comprehensive collection infrastructures and consumer awareness have also significant roles in achieving an economically efficient and environmentally conscious management of WEEE.

The aim of this paper is to provide an overview of the WEEE Directive and its implementation to national legislations in Finland, Sweden, and Norway and, in addition, describe how the nationwide WEEE recovery infrastructures have been built in these Nordic countries. Furthermore, the WEEE recovery networks are compared and collection efficiencies of the national systems are evaluated based on the EU statistics on amounts and sources of the collected WEEE. Finally, best practices of WEEE management in the Nordic countries are expressed.

This paper is based on personal professional experiences and academic research conducted over the last 10 years in Finland and Norway. The study is explorative in nature and it rests on a literature review and personal notifications from Finnish, Swedish, and Norwegian real-life experiences. Notifications from various representatives of national authorities and WEEE operators were conducted through personal encounters in professional positions, e-mail enquiries, personal interviews carried out during company visits, and person-to-person discussions in public events related to the topic of this work.

\section{An Overview of the European Waste Electrical and Electronic Equipment (WEEE) Directive}

2.1. Main Principles Included in the WEEE Directive. The polluter pays principle (PPP), which makes those responsible for environmental pollution accountable for it, was launched by the Organisation for Economic Cooperation and Development (OECD) already in 1972. Nowadays, PPP is one of the fundamental principles of the European Community environmental policy and it encourages preventing and reducing pollution and, therefore, it has also been included in the RoHS (restriction of hazardous substances) and WEEE (waste electrical and electronic equipment) Directives. In the RoHS Directive, the requirement of substitution of hazardous substances for safer materials follows the principle of PPP for pollution prevention, while PPP is included in the WEEE Directive in the form of extended producer responsibility (EPR). EPR for the waste management phase of EEE was regulated in order to create an economic incentive for producers to move towards more environmentally sound design and manufacturing [3]. Therefore, the establishment of the WEEE Directive aimed at encouraging producers to consider the design and production of EEE in relation to end-of-life (EOL) management, an approach that takes into account and facilitates their repair, possible upgrading, reuse, disassembly and recycling, and, finally, the best methods of recovery and disposal.

The other fundamental principles built into the WEEE Directive are the principles of subsidiarity and proportionality. The purpose of subsidiarity is to ensure that powers are exercised as close to the citizen as possible. In the European community context, subsidiarity protects the member states' capacity to take decisions and actions; however, it also authorizes the intervention of the community when the objectives cannot be achieved sufficiently by the member states "due to the scale and effects of the proposed action" [4]. The principle of proportionality, for one, introduces only obligations which are necessary to achieve, not the measures of the execution. In accordance with subsidiarity, national and regional conditions have to be taken into account when collection, treatment, and financing systems for the management of WEEE are devised. Therefore, the WEEE Directive describes only the main principles of WEEE management and financing and, further, the establishment of principles at the community level. In contrast, the modalities of the logistics and the organization of the take-back schemes are left to the choice of the member states [1]. Further, in accordance with the proportionality principle, the minimum targets of $70 \mathrm{w} \%$ for recovery and $50 \mathrm{w} \%$ for reuse and recycling of WEEE are set in the Directive [3].

2.2. The Initial WEEE Directive 2002/96/EC. The WEEE Directive 2002/96/EC was signed in January 27, 2003, and put in effect in February 13, 2003, by publishing in the Official Journal of the European Union. At the same time, also the RoHS Directive (2002/95/EC) was introduced, to ban the use of six hazardous substances (lead, mercury, cadmium, hexavalent chromium, polybrominated biphenyls (PBBs), and polybrominated diphenyl ethers (PBDEs)) in electrical and electronic equipment.

The principal purposes of the WEEE Directive 2002/96/ EC were to prevent WEEE generation and, in addition, to improve the reuse, recycling, and recovery of WEEE, in place of disposal, to reduce the environmental and health impacts of WEEE. Further, it seeks to harmonize the member states' national measures on the management of WEEE in order to avoid national approaches which may hamper the effectiveness of recycling policies and cause substantial disparities in the financial burden at the EU level. These objectives are expected to be achieved by a wide range of requirements from operators involved in the life-cycle of EEE, including producers, consumers, and, in particular, operators directly involved with the WEEE treatment [3].

Directive 2002/96/EC defines EEE as equipment that is dependent on electric current or electromagnetic field to work and equipment for the generation, transfer, or measurement of such currents and fields. The voltage rating ranges between $0-1000 \mathrm{~V}$ for $\mathrm{AC}$ and $0-1500 \mathrm{~V}$ for DC. The scope of the Directive includes practically all electrical and electronic equipment falling under the definition, excluding only 
TABLE 1: The minimum targets of the European WEEE Directive 2002/96/EC [3].

\begin{tabular}{llcc}
\hline & Category & Recovery rate [w\%] & Reuse and recycling rates [w\%] \\
\hline 1 & Large household appliances & 80 & 75 \\
2 & Small household appliances & 70 & 50 \\
3 & IT and telecommunications equipment & 75 & 65 \\
4 & Consumer equipment & 75 & 65 \\
5 & Lighting equipment & 70 & 50 \\
6 & Gas discharge lamps & - & 80 \\
7 & Electrical and electronic tools & 70 & 50 \\
8 & Toys, leisure, and sports equipment & 70 & 50 \\
9 & Monitoring and control instruments & 70 & 50 \\
10 & Automatic disperser & 80 & 75 \\
\hline
\end{tabular}

equipment intended for military purposes such as arms and munitions [3]. Due to the extremely wide range of equipment, EEE is categorized in the Directive 2002/96/EC as can been seen in Table 1. Separate collection is the precondition to ensure specific treatment and recycling of WEEE. Therefore, according to Directive 2002/96/EC, producers need to oversee the finance for the development of appropriate systems, so that returning WEEE for recovery is reasonably easy and free of charge for private people. Further, a general collection target for WEEE categories, $4 \mathrm{~kg} /$ inhab./year, was provided and it had to be achieved by December 31,2006, the latest [3].

Producers also had to set up appropriate systems in order to ensure improved treatment and reuse/recycling of WEEE. Certain requirements for treatment are prescribed in Directive 2002/96/EC as targets for the reuse, recycling, and recovery of WEEE. Treatment requirements, recovery rates of up to $80 \%$ by an average weight, and recycling rates of up to $75 \%$ by an average weight per appliance had to be realized by December 31, 2006, as well. The specific recovery and recycling targets of different WEEE categories set in the Directive are presented in Table 1 [3].

In order to achieve high collection rates and to facilitate the recovery of WEEE, users of EEE and recyclers must be informed about their role in the recovery system of WEEE. Therefore, a labelling requirement for EEE put on the market after August 13, 2005, has been set to minimize the disposal of WEEE as unsorted municipal waste and requirements for producers to inform recycling operators about the material content of such equipment. The symbol for marking EEE is shown in Figure 1 [3].

According to Directive 2002/96/EC, within five years after entry to force, experiences from the application of the Directive, especially regarding separate collection, treatment, recovery and financial systems had to be reported. Also recasting of the Directive had to be suggested, if appropriate. Simultaneously, the new mandatory targets for recovery, recycling, and reuse of WEEE had to be established by December 31, 2008, at the latest [3]. The time line of deadlines and important dates of the WEEE Directive 2002/96/EC are illustrated in Figure 2.

2.3. The Recast Directive 2012/19/EU on WEEE. According to the impact assessment of the WEEE Directive, done in

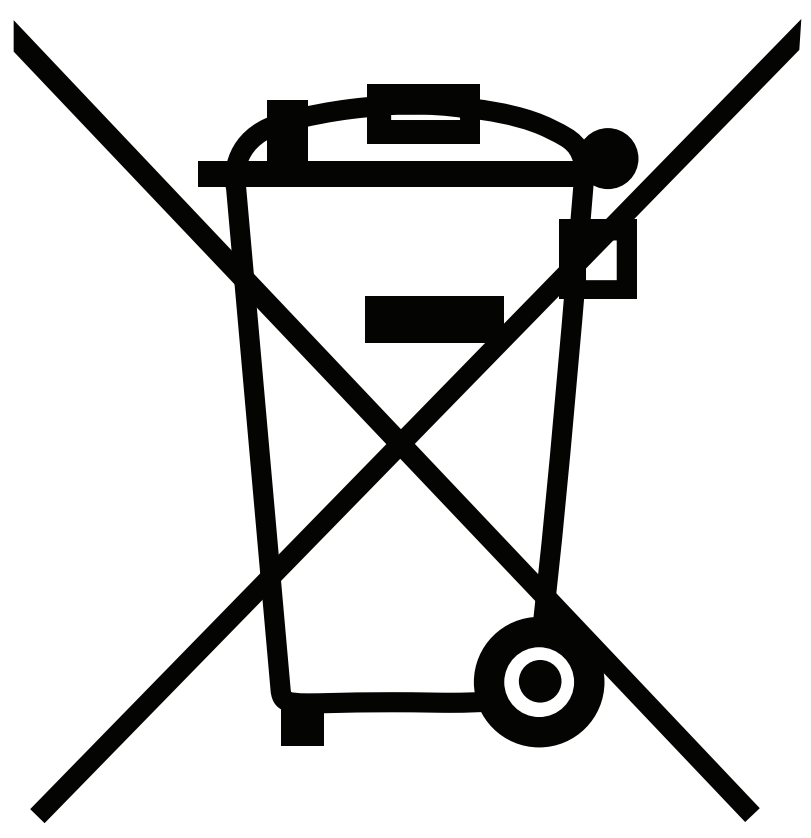

FIGURE 1: Symbol for the marking of EEE [3].

2008, during the first years of implementation some technical, legal and administrative problems, such as low levels of innovation in waste collection and treatment as well as distortion in competition, were observed [5]. The WEEE Directive 2002/96/EC itself foresaw the possibility of revision based on the experiences of the application. In addition, it set out to propose new mandatory WEEE collection, recovery, and reuse/recycling targets by the end of 2008. The proposal of the recast WEEE Directive $\{\mathrm{COM}(2008) 810$ final $\}$ was introduced in December 3, 2008. After the revising process, the recast WEEE Directive 2012/19/EU was signed on July 4,2012 . In consequence, the initial WEEE Directive with its successive amendments was repealed on February 15, 2014.

The main tasks of revision were to increase separate collection and proper treatment by establishing a collection rate ambitious and appropriate for each member state and fight illegal exports of e-waste disguised as "used equipment" by reversing the burden of proof on functionality for exporters. Further, lower administrative burdens in the internal market by simplifying registration and reporting requirements for 


\begin{tabular}{|c|c|c|c|c|}
\hline $\begin{array}{l}\text { June } 13,2000: \\
\text { Proposal of } \\
\text { WEEE Directive } \\
\text { introduced. }\end{array}$ & $\begin{array}{l}\text { February 13, 2003: } \\
\text { WEEE (2002/96/EC) } \\
\text { Directive put into } \\
\text { force. }\end{array}$ & $\begin{array}{l}\text { August } 13,2004: \\
\text { Deadline for member } \\
\text { states to transpose } \\
\text { WEEE Directive into } \\
\text { national legislation. }\end{array}$ & \multicolumn{2}{|c|}{$\begin{array}{l}\text { December 31, 2006: } \\
\text { Deadline to achieve WEEE targets: } \\
>4 \mathrm{~kg} / \text { inhab./year for separate collection, } \\
70 / 75 / 80 \mathrm{w} \% \text { for recovery, } \\
>50 / 65 / 75 \mathrm{w} \% \text { for reuse and recycling. }\end{array}$} \\
\hline & $\begin{array}{l}\text { January 27, 2003: } \\
\text { WEEE Directive } \\
\text { (2002/96/EC) signed by } \\
\text { the European Parliament } \\
\text { and Council. }\end{array}$ & $\begin{array}{l}\text { August } 13,200 \\
\text { Separate collec } \\
\text { recovery, and } \\
\text { disposal of WE } \\
\text { financed by pr } \\
\text { New EEE prod } \\
\text { separate collec }\end{array}$ & $\begin{array}{l}\text { on, treatment, } \\
\text { vironmentally sound } \\
\text { E arranged and } \\
\text { lucers. } \\
\text { cts marked with the } \\
\text { on symbol. }\end{array}$ & $\begin{array}{l}\text { December 31, 2008: } \\
\text { Deadline for proposal of } \\
\text { new mandatory targets } \\
\text { of recovery, recycling, } \\
\text { and reuse of WEEE. }\end{array}$ \\
\hline
\end{tabular}

FIgURE 2: Time line of implementation of the European WEEE Directive 2002/96/EC based on [3].

TABLE 2: The minimum targets of recovery, reuse, and recycling rates in the WEEE Directive 2012/19/EU [7].

\begin{tabular}{|c|c|c|c|c|}
\hline & Category & $\begin{array}{l}\text { Recovery/reuse and } \\
\text { recycling targets [\%] } \\
\text { in period } 1^{*}\end{array}$ & $\begin{array}{l}\text { Recovery/reuse and } \\
\text { recycling targets [\%] } \\
\text { in period } 2^{* *}\end{array}$ & $\begin{array}{l}\text { Recovery/reuse and } \\
\text { recycling targets [\%] } \\
\text { in period } 3^{* * *}\end{array}$ \\
\hline 1 & Large household appliances & $80 / 75$ & $85 / 80$ & \\
\hline 2 & Small household appliances & $70 / 50$ & $75 / 55$ & \\
\hline 3 & IT and telecommunications equipment & $75 / 65$ & $80 / 70$ & \\
\hline 4 & Consumer equipment & $75 / 65$ & $80 / 70$ & \\
\hline $5 \mathrm{a}$ & Lighting equipment & $70 / 50$ & $75 / 55$ & \\
\hline $5 b$ & Gas discharge lamps & $-/ 80$ & $-/ 80$ & \\
\hline 6 & Electrical and electronic tools & $70 / 50$ & $75 / 55$ & \\
\hline 7 & Toys, leisure, and sports equipment & $70 / 50$ & $75 / 55$ & \\
\hline 8 & Medical devices & $70 / 50$ & $75 / 55$ & \\
\hline 9 & Monitoring and control instruments & $70 / 50$ & $75 / 55$ & \\
\hline 10 & Automatic disperser & $80 / 75$ & $85 / 80$ & \\
\hline 1 & \multicolumn{3}{|c|}{ Temperature exchange equipment (e.g. refrigerators and heat pumps) } & $85 / 80$ \\
\hline 2 & \multicolumn{3}{|c|}{ Screens and monitors (e.g. televisions, LCD, and photo frames) } & $80 / 70$ \\
\hline 3 & \multicolumn{3}{|c|}{ Lamps (e.g. fluorescent lamps and LEDs) } & $-/ 80$ \\
\hline 4 & \multicolumn{3}{|c|}{ Large equipment (e.g. washing machines and photovoltaic panel) } & $85 / 80$ \\
\hline 5 & \multicolumn{3}{|c|}{ Small equipment (e.g. vacuum cleaners, smoke detectors, and sport equipment) } & $75 / 55$ \\
\hline 6 & \multicolumn{3}{|c|}{ Small IT and telecommunication equipment (e.g. mobile phones, GPS, and personal computers) } & $75 / 55$ \\
\hline
\end{tabular}

* Period 1: from August 13, 2012 until August 14, 2015.

** Period 2: from August 15, 2015 until August 14, 2018.

*** Period 3: from August 15, 2018 onwards.

new equipment placed on the market were also in target [6]. In the recast process, also the scope of the Directive was clarified by defining categories of equipment as from private household ("consumer-to-business", C2B) or from users other than private households ("business-to-business", B2B). This is expected to result in positive environmental and economic impacts and clarity for producers by reducing free-riding in the market.

In the recast WEEE Directive, electrical and electronic devices have been recategorized. According to Directive 2012/19/EU, EEE categories follow the initial ones over to the transitional period from August 13, 2012, to August 14, 2018, with an extension of photovoltaic panels to category 4. From August 15, 2018, onward, the Directive applies to all EEE categorized as introduced in Table 2. The more demanding and gradually evolved collection and recycling targets of WEEE are included in the recast Directive (Table 2). In the initial stage, over the first three years, the recovery, reuse, and recycling targets remained at the previous level. However, the scope of the recovery and recycling targets was extended to cover also medical devices (category 8) with the expectation of $70 \%$ recovery and $50 \%$ reuse and recycling at EOL. Moreover, a rate of separate collection of at least $4 \mathrm{~kg} /$ inhab./year of WEEE from private households, or the same amount of WEEE that was collected in the three preceding years, whichever is greater, has to be collected [7]. In the following stage, from three to seven years, all targets will be raised by $5 \%$, with recycling rates ranging from 55 to $80 \%$ and recovery rates from $75-85 \%$. Eventually, after the transitional period of seven years, new categories of WEEE will come into effect, when some changes in targets may occur due to recategorization. In 2019, collection targets will be 


\begin{tabular}{|c|c|c|c|}
\hline $\begin{array}{l}\text { December 18, 2008: } \\
\text { Proposal of the recast } \\
\text { WEEE Directive } \\
\text { introduced. }\end{array}$ & $\begin{array}{l}\text { August 13, 2012: } \\
\text { The recast WEEE } \\
\text { Directive } \\
\text { put into force. }\end{array}$ & $\begin{array}{l}\text { February 15, 2014: } \\
\text { Deadline for member } \\
\text { states to transpose } \\
\text { recast WEEE Directive } \\
\text { into national legislation. } \\
\end{array}$ & $\begin{array}{l}\text { August 15, 2018: } \\
\text { Implementation of new } \\
\text { WEEE categorizations } \\
(10 \rightarrow 6) \text { and their } \\
\text { minimum targets. }\end{array}$ \\
\hline & $\begin{array}{l} \\
\text { July 4, 2012: } \\
\text { The recast WEEE } \\
\text { Directive signed by the } \\
\text { European Parliament and } \\
\text { Council. }\end{array}$ & $\begin{array}{l}\text { August 15, 2015: } \\
\text { Deadline to achiev } \\
\text { targets for WEEE } \\
>75 / 80 / 85 \mathrm{w} \% \text { fo } \\
>55 / 70 / 80 \mathrm{w} \% \text { fo }\end{array}$ & $\begin{array}{l}\text { new, stricter minimum } \\
\text { tegories. } \\
\text { recovery, } \\
\text { reuse and recycling. }\end{array}$ \\
\hline
\end{tabular}

FIGURE 3: Time line of implementation of the recast WEEE Directive 2012/19/EU based on [7].

TABLE 3: Demographics of Finland, Sweden, and Norway compared to EU27 in 2012 [11].

\begin{tabular}{lccc}
\hline Country & $\begin{array}{c}\text { Area } \\
{\left[\mathrm{km}^{2}\right]}\end{array}$ & $\begin{array}{c}\text { Population } \\
{[\text { millions }]}\end{array}$ & $\begin{array}{c}\text { Pop. Density } \\
{\left[\text { inhab./km }{ }^{2}\right]}\end{array}$ \\
\hline Finland & 338,400 & 5.4 & 18 \\
Sweden & 438,600 & 9.5 & 23 \\
Norway & 323,800 & 5.0 & 16 \\
EU27 & $4,406,000$ & 501.8 & 114 \\
\hline
\end{tabular}

specific for each member state; the minimum collection rate will be $65 \%$ of the average weight of EEE placed on the market in the three preceding years or, alternatively, $85 \%$ of WEEE generated [7].

To ensure that all WEEE is treated properly in the member states, Directive 2012/19/EU requires that the European standardization organisations develop standards for recovery, recycling, and preparing for reuse of WEEE by no later than February 14, 2013. Further, the registration and reporting requirements of national registers to the commission are harmonized in Directive 2012/19/EU for reducing unnecessary administrative burden between the member states and EU and the minimum inspection requirements for the member states are set in order to bridge the implementation gap, as well. Further, minimum monitoring requirements for shipments of WEEE are enacted to strengthen the enforcement of the WEEE Directive [7]. The time line of deadlines and important dates of the WEEE Directive 2012/19/EU is illustrated in Figure 3.

\section{Characteristics of the Nordic Countries}

Finland, Sweden, and Norway are relatively large and sparsely populated countries situated in Northern Europe (Table 3). As it can be seen from Figure 4, population is strongly concentrated in the southern parts of these three countries. In Finland, the most populous area is the Helsinki Capital Region (cities of Helsinki, Espoo, Vantaa, and Kauniainen) in the south coast of Finland with 1.1 million inhabitants, while Stockholm, the Swedish capital city in the east coast, has a population of around 1.25 million. Also in Norway, the capital city Oslo, in the south coast with more than 925,000 million inhabitants, is the most densely populated area of the country. In addition to these populous capital city areas, there are 300400 municipalities in each country, half of which have no more than 5000 residents [8-10].
Large unpopulated northern areas, long distances, and a cold climate with long and snowy winters are typical characteristics of the Nordic countries. They also have much in common in the way of life, history, language, and social structure with high equality. Due to challenging weather conditions and high living standards, EEE has become an important part of Scandinavians' everyday life and, further, applications of information and communication technologies (ICT) are highly implemented in Nordic societies.

\section{WEEE Recovery in Finland}

4.1. Legislative Implementation in Finland. Prior to the implementation of the WEEE Directive, neither the legislative nor the operational preconditions to a nationwide, comprehensive separate collection and recovery system of WEEE existed in Finland. In order to harmonize Finnish waste legislation with the WEEE Directive, in June 2004 the Finnish Waste Act (1072/1993) was amended (452/2004) to include new clauses on producer responsibility. Moreover, governmental regulations of WEEE (852/2004) and RoHS (853/2004) were incorporated to the national legislation in September 2004. Later on, the Finnish Waste Act was reformed due to the implementation of the Waste Framework Directive (2008/98/EC) and incoherence caused by several amendments. No outstanding changes in producer responsibility on EEE were done at that time, however, roles and responsibilities of various actors were clarified and the mandate of the national inspecting and controlling authority was enhanced. The reformed Waste Act (646/2011) took effect on May 1, 2012, with an exception of articles concerning producer responsibility, which entered into force on May 1, 2013. A detailed description of the legislative implementation of the WEEE Directive in Finland is presented by Ylä-Mella et al. [13].

In spite of the recent reform of the Waste Act, the Finnish Waste legislation is required to be revised due to adaption of the recast WEEE Directive (2012/19/EU) into national law. Therefore, the amendment of the Finnish Waste Act (646/2011) has been passed in March 2014 and the revised Government Degree on WEEE (519/2014) has been issued in July 2014.

4.2. The Finnish WEEE Recovery Infrastructure. The overwhelming majority of electronic devices sold in the Finnish market are imported and, therefore, the representatives of 


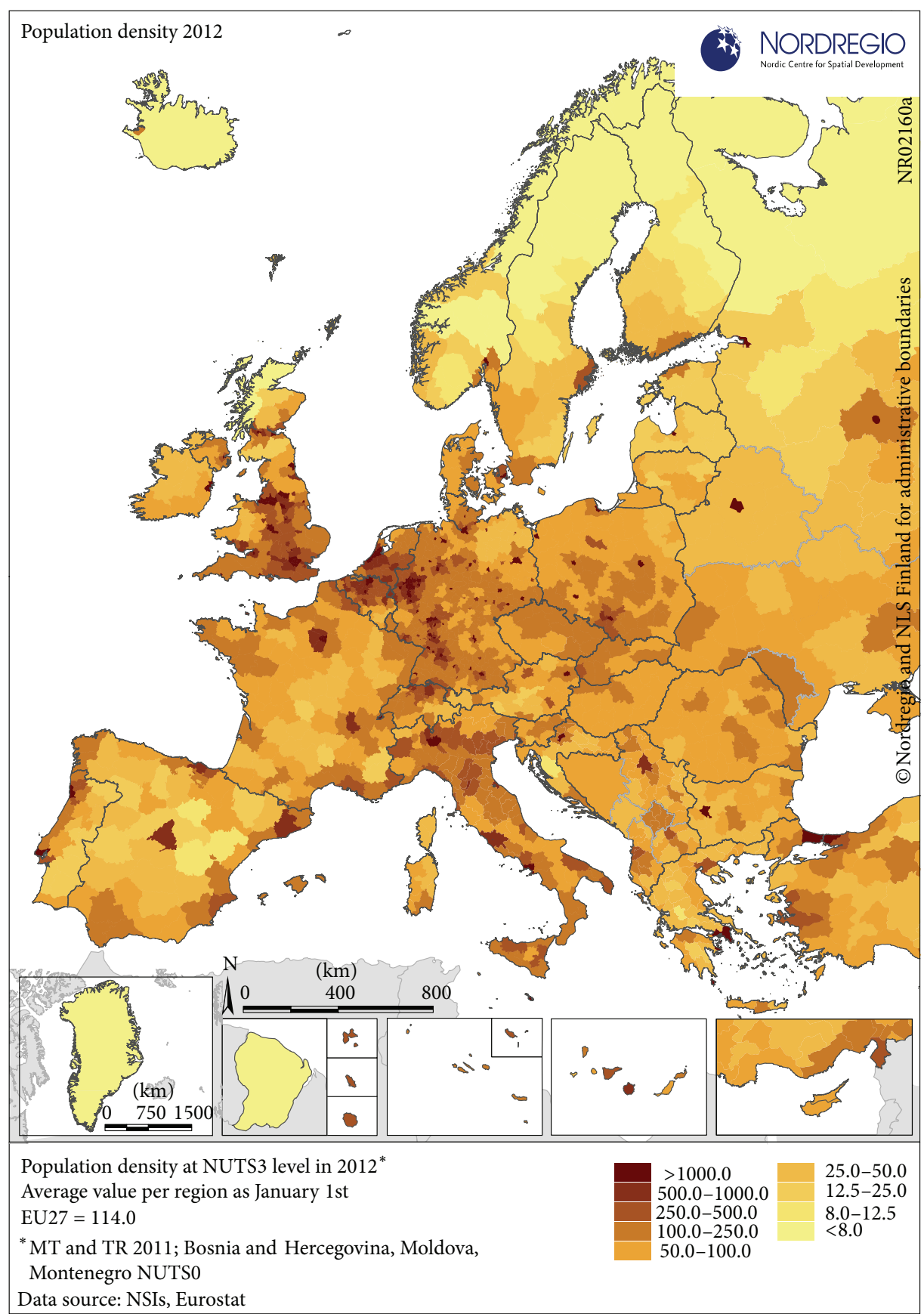

FIGURE 4: Population density in Europe in 2012 [12].

foreign and domestic producers may transfer responsibility over discarded electronics to a producers association. The producers association in turn appoints WEEE recovery companies to treat and recycle the collected waste. In Finland, electrical and electronic equipment producers and importing business have formed five producer associations for the purpose of organizing collection and recycling of WEEE. Three of them, FLIP ry (Finnish Lamp Importers and Producers Association), ICT-tuottajaosuuskunta (ICT Producer Co-operative), and SELT ry (Electrical and Electronics Equipment Producers' Association), have founded together an umbrella organization and service provider named Elker
Ltd. The other two, SER-tuottajayhteisö ry SERTY (The Association of Electric and Electronic Producers and Importers) and ERP Finland (European Recycling Platform Finland), operate independently. Within the supply chain of WEEE, various tasks such as collection, transportation, sorting and disassembly of products, storage, selling of material fractions and reusable products and parts is conducted. The main stages of the WEEE recovery system in Finland are presented in Figure 5 modified from [13].

In the building phase of the Finnish WEEE recovery system, two diverse structures of the supply chain were built. SERTY and NERA (current ERP Finland) both had 


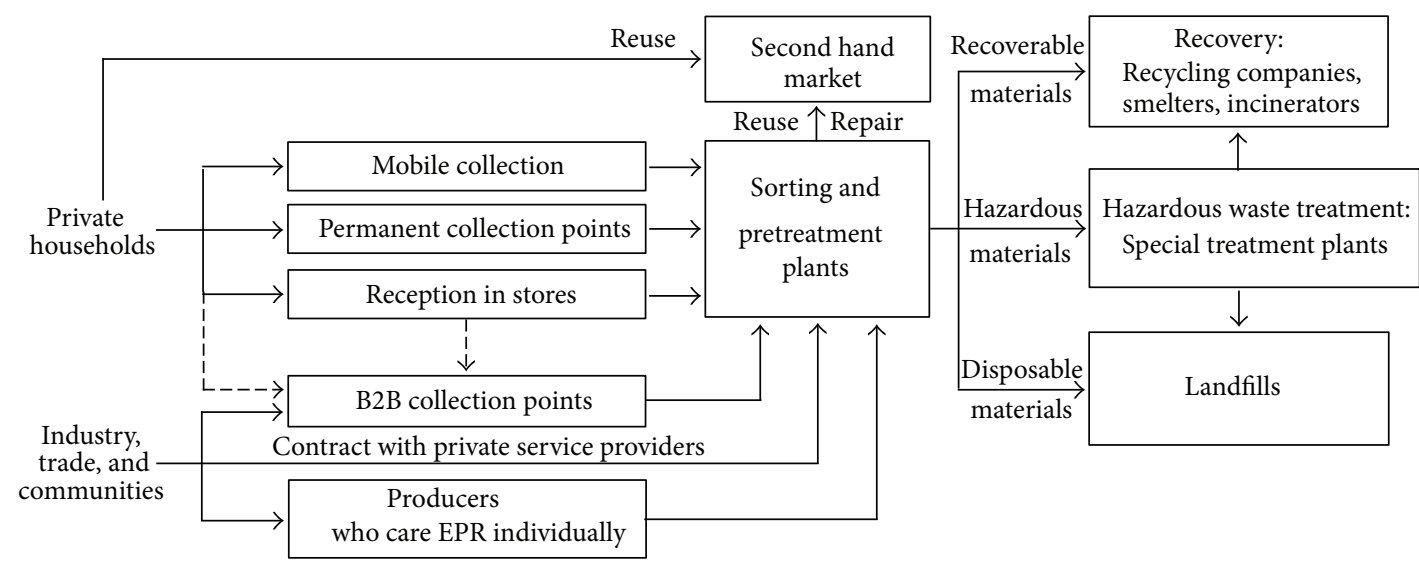

FIgURE 5: The main stages of the WEEE recovery system in Finland based on [13].

their own centralized reverse supply chains, where WEEE was transported nationally from collection points to only a few treatment points. Elker, on the other hand, promoted a nationwide decentralized logistics network with over 30 pretreatment stations and several transport service providers. Logistics services were typically sourced from regional operators, such as from social enterprises or public institutions. Regional handling of WEEE also included the sorting of collected WEEE into reusable and recoverable fractions. After the first operating years, producers associations have begun to collaborate more and, in consequence, SERTY and ERP Finland have also moved towards a more decentralised system with several regional contractors and, nowadays, most of the reception points are collectively financed by the producers associations [13].

Collection and transportation are generally the most expensive steps of the WEEE supply chain and, therefore, it is crucial to set up an efficient collection system [14, 15]. The collection of WEEE can be organized in several different ways; however, the three most common ones are municipal sites, in store retailer take-back, and producer take-back $[16,17]$. The methods generally used for WEEE collection are drop-off programs, pick-up programs, and distance collection [18]. In drop-off programs, consumers can return discarded devices to permanent collection centres, to retailers, or to containers located in public places such as on the streets. Drop-off collection programs can also be implemented as temporary collection events. Municipal collection sites for WEEE are highly cost effective because facilities require minimal upgrading, while collection points at retail shops have been found to be successful due to the convenience to users [17]. In pick-up systems, WEEE is collected directly from homes or offices of the last users as a regular curb side collection or, optionally, scheduled pickup together with other separately collected waste fractions [17-19]. In distance collection, the last user sends discarded devises to the collector or recycler through public postal services. This method is consumer-friendly as it provides an easy return process for consumers; however, it has a relatively high cost of logistics [19].

In Finland, collection of WEEE is arranged mainly as a permanent collection; in 2011, approximately 450 collection points existed around the country [20]. Permanent collection points are, in most cases, provided by the municipality and, in some cases, by private companies or social enterprises. Private users and households can bring their EOL products to the collection points free of charge. Nonprivate users, such as enterprises and institutes, are, generally, not allowed to return WEEE to collection points of the network but have an individual contract with local operators to remove their electronic equipment straight to the regional WEEE sorting and pretreatment plants of private service providers. In case of consumer WEEE being used in companies, those can be returned to certain business-to-business (B2B) reception points managed by producer associations and located in connection with sorting and pretreatment plants operated by private service providers [13].

However, a permanent collection system is not efficient in all cases, for example, because of the quantity of returned devices [21]. Therefore, in the smallest or the most sparsely populated municipalities of Finland, the recovery of WEEE has been organized as a mobile collection once or twice a year. End-of-life EEE can also be returned to the retailers in association with buying a new, corresponding device. Further, since May 1, 2013, small WEEE including lighting equipment (all dimensions no more than $25 \mathrm{~cm}$ ) can be also returned with no purchase obligation to electronics shops with area larger than $200 \mathrm{~m}^{2}$ or to grocery shops of $1000 \mathrm{~m}^{2}$ minimum [22]. There are no exact guidelines for the implementation of in-store reception in Finland; however, shops are required to finance and organise the place, the requisites, and the work contributions needed to receive WEEE. Distributors may forward the received WEEE to $\mathrm{B} 2 \mathrm{~B}$ reception points of official collection network by themselves or, alternatively, they may enroll in a distributors register in order to obtain free unloading services financed by producers associations. After registration, distributors may purchase certain combo receivers designed especially for small WEEE or get free of charge a special collection requisite for data WEEE, if such kinds of devices are included in the distributor's product range. According to The Association of Electric and Electronics Manufacturers and Importers (SERTY), around 1500 distributors and shops have enrolled in the distributors' register of Finland in the beginning of 2014. It is estimated 
that around 1000 shops are still missing from the register, partly due to challenges to arrange a physical space for instore collection or due to low amounts of received WEEE [23].

From the local collection points, WEEE is transported by private transportation providers contracted by producers associations to regional sorting and pretreatment stations situated across the country. In the regional sorting plants, WEEE is manually separated, for different product cooperatives, weighed, and sorted into reusable and not reusable fractions. Reusable equipment and components are manually sorted, stocked, and delivered onwards, while recyclable devices are directed for pretreatment. During pretreatment, WEEE is manually disassembled to fulfil requirements for selective treatment of hazardous materials set in Annex VII of the recast WEEE Directive. Hazardous materials, such as lead, mercury, cadmium, or chlorofluorocarbons (CFCs), and certain components containing hazardous substances (e.g., cathode ray tubes (CRT) and LCD screens, batteries, backlighting lamps, cables, and printed circuit boards) are required to be removed before the actual treatment of WEEE [7]. Also large monomaterial parts are manually separated before crushing the WEEE. Crushed WEEE is then mechanically sorted out as metal, glass, and plastic fractions before being delivered onwards for recovery. Metals and glass are taken to smelters or reprocessing plants, while plastics are currently mainly utilised as energy in incinerators. Nonrecyclable WEEE parts and materials are taken to special treatment plants or for final disposal. For instance, fluorescent lamps and other compounds containing heavy metals are treated in a physicochemical treatment plant, where neutralisation, oxidation, reduction, and precipitation take place in batch processes, selected based on the type of waste being treated. Insoluble heavy metal precipitates produced in reactions are later on disposed of at special landfills for hazardous wastes. High temperature incineration is also applied as a final disposal method for certain hazardous materials such as plastics containing brominated flame retardants [24]. Finally, data on the quantities of various WEEE fractions and operations performed in the sorting and pretreatment stations are sent to producers' cooperatives.

4.2.1. Development of a Nationwide Recovery Network: Case Elker Ltd. Elker Ltd. is a nonprofit service company established in 2004 by the Finnish producer organisations SELT Association, ICT Producer Cooperative, and FLIP Association. Elker Ltd. has been established as a company providing centralised services to manage practical affairs related to obligations set out in the WEEE Directive and to fulfil the corresponding obligations of the Finnish legislation. In 2005, approximately 550 member companies were joined to the producer associations of SELT, ICT, and FLIP. The expansion of Elker Ltd. has been rapid in the first years; in 2006, there were 700 member companies, while only three years later, in 2010, almost 1000 companies were members of Elker.

To fulfil the requirement of separate collection, Elker built up a nationwide collection network for WEEE. In the implementation phase of the WEEE Directive, the Finnish inspecting and controlling authority of WEEE, the Pirkanmaa Regional Environment Centre, set requirements for the extent and coverage of this network. In the case of Elker, at the minimum requirement, there were 340 permanent collection points in 235 municipalities. In addition to permanent collection, Elker had carried out mobile collection in municipalities without permanent collection points. By the end of 2006, Elker built the network of 390 permanent collection points in 250 of most populous municipalities. Further, mobile collection was carried out twice a year. The management of permanent Elker collection points are provided chiefly by municipal waste companies and are typically located in the premises of said companies. In case of mobile collection, Elker appoints the dates and places case-specifically with the municipality in question.

From the point of view of Elker, the main challenges of the development of the nationwide collection network were related to the smallest collection points, where the physical space of collection cages was limited and the amounts of returned WEEE varied substantially. Therefore, Elker has launched reception points for B2B WEEE, which are also open for private consumers with larger batches of WEEE. The other remarkable challenge has been the leakage of WEEE outside the official network. Valuable WEEE is captured by unofficial channels, while only the WEEE with low or negative value remains the responsibility of producers associations. This unhealthy competition in WEEE collection and recovery resulted in increased operational costs and, further, decreased the cost-effectiveness of WEEE recovery network under producer responsibility.

4.2.2. An Example of a WEEE Collection Supported by a Manufacturer: Case Nokia. Regardless of numerous methods suitable for WEEE collection, a large fraction of small unused EEE does not enter the WEEE recovery systems [25] but lies around not in use or, even worse, is disposed of in inappropriate ways such as with mixed waste [26-29]. Nokia, the well-known former Finnish mobile phone manufacturer, worked for several years to raise consumer awareness and improve the recycling behaviour of consumers. Nokia has, for instance, organized cooperation programs with telecom operators, retail companies, environmental nongovernmental organizations (NGOs) and educational institutes, direct consumer campaigns, and university events. In addition to permanent take-back locations in almost 100 countries, Nokia has also developed alternative channels for consumers [30].

In Finland, Nokia is taking part in maintaining the WEEE collection network as a member of Elker Ltd. In addition, Nokia has set up authorized service points and special collection bins (see Figure 6). From Nokia's point of view, takeback bins are a visible collection method to raise awareness and suitable to use in closed or semiclosed communities such as in company premises. However, the use of bins may be challenging from a logistics point of view because bins need to be located in easily accessible and secure locations with an economically viable logistics solution to empty the bins regularly [30].

Another consumer-friendly method to return old mobile phones, batteries, and accessories is prepaid mail-back enve- 


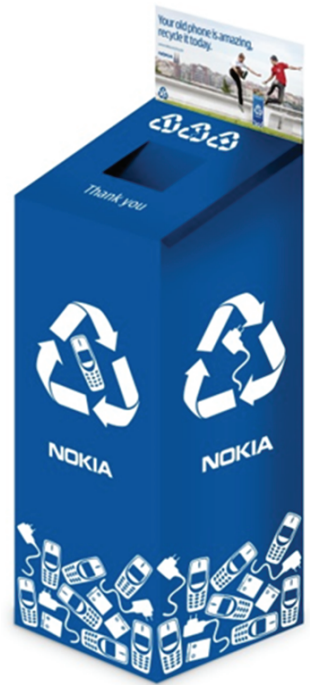

Figure 6: A collection bin for mobile phones [30].

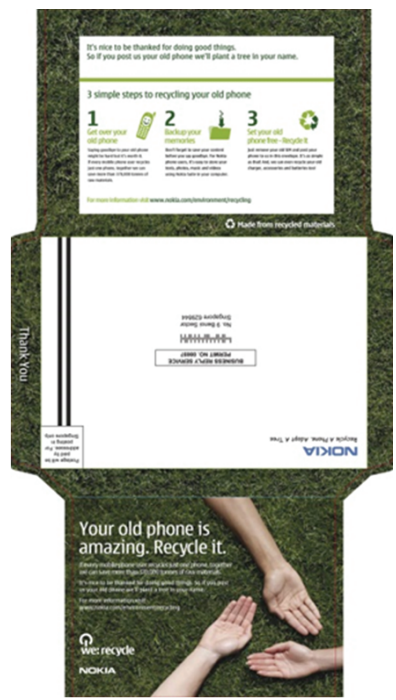

Figure 7: A return envelope for mobile phones [30].

lopes (see Figure 7), which can be dropped off in the nearest mailbox. The envelopes can be mailed directly to the consumers, distributed in retail shops, or included in the sales package of a new product, and prepaid postage and addresses can be downloaded and printed from the Internet. The drawbacks of this method are economic inefficiency and logistics in case of large volumes [30].

\section{The WEEE Recovery in Sweden}

5.1. National WEEE Legislation in Sweden. Sweden is one of the European frontrunners in WEEE recovery. Sweden has implemented the law of producer responsibility for electrical and electronic producers in 2001 and launched an operational recycling system of WEEE in 2002. The WEEE Directive (2002/96/EC) has been implemented in the form of the ordinance of producer responsibility for electrical and electronic products (Swedish Code of Statutes 2005:209) issued on April 14, 2005. Recently, the adaptation of the recast WEEE Directive (2012/19/EU) to the Swedish regulations has been initiated in 2012, and the work has continued through 2013. It is expected to be completed in 2014 [31].

5.2. The Swedish WEEE Recovery Infrastructure. The Swedish system is recognized as one of the most effective WEEE recovery systems in the world not only due to the high amounts of WEEE per inhabitant collected annually (more than $16 \mathrm{~kg} /$ inhab./year since 2007), but also due to costs [32, 33]. In Sweden, two producers' responsibility organisations exist to service Swedish EEE producers and manufacturers and are responsible for the management of WEEE recycling. El-Kretsen, established in 2001, is owned by 20 business associations and runs on a not-for-profit basis. El-Kretsen has currently 1300 affiliated companies undertaking the agreement for electrical and electronic products and about 700 customers undertaking the agreement for batteries as defined in the Swedish laws SFS 2005:209, 210 and SFS $2008: 834$, when the charges paid by the affiliated members are based on their own costs. El-Kretsen collects the major proportion of Swedish WEEE as its total share of WEEE collection was around $80 \%$ in 2012. For household collection of WEEE, called "Elretur," El-Kretsen makes contracts with municipalities and, in the case of business collection, with other collecting organisations. In 2012, there were approximately 600 municipal recycling centres in operation for all WEEE categories and, further, almost 2000 collection stations for small electronics, batteries, and lighting equipment in Swedish municipalities. Household collection is organised in cooperation with Swedish municipal authorities [31].

The other Swedish operator of WEEE, the Swedish Association of Recycling Electronics Products (EÂ), has provided WEEE collection points in retail stores nationwide since 2008. In 2012, its share of collected WEEE in Sweden was around $20 \%$. The EÅF system is parallel with the ElKretsen's system; however, because not all municipalities have an EÅF's reception point in retail stores, EÅF pays a fee for the part of its members' WEEE that is collected by El-Kretsen [32]. In addition to these municipal and in-store collection systems, there are trials of property-close source collection of WEEE in some Swedish city centres with good results [3436].

In addition to networks of free collection for households, there were also around 550 private collection points for companies and organisations in 2012. Collection from organisations is partly organised in cooperation with municipal authorities and partly through directly contracted transporters. In addition, collection services for certain types of products, such as light sources, are provided by ElKretsen [31]. It is important to note that, in Sweden, disposal services are free of charge also for business. This is due to using a return certificate, through which the party, who disposing of the object, guarantees that the number of units returned corresponds with the undertaking's purchase of new equipment [33].

At the recycling centres, products are sorted into the following seven categories [31]: (1) assorted electrical goods, 


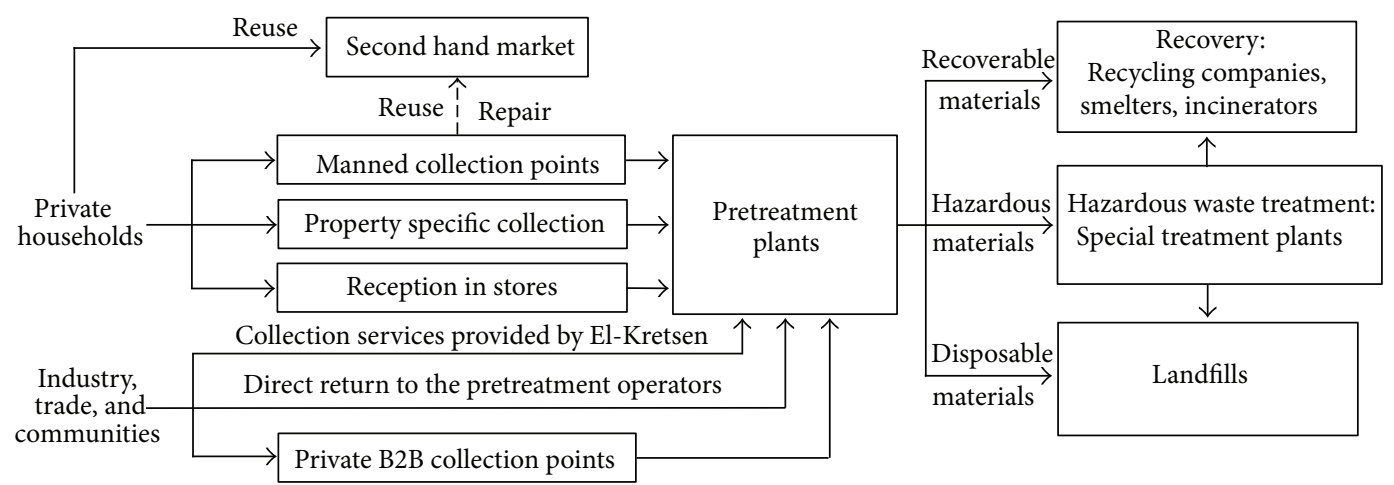

FIgURE 8: The main stages of the WEEE recovery system in Sweden based on $[31,33]$.

(2) televisions and monitors, (3) fridges and freezers, (4) large white goods, (5) lighting, (6) fluorescent tubes, and (7) portable batteries. After being deposited at the collection points, WEEE is transported onwards to the recycling plants chosen by El-Kretsen, where the products are unloaded and registered before undergoing initial sorting and disassembly. Disassembly involves removing environmentally hazardous substances and components that require special processing set in the Annex VII of the recast WEEE Directive, for example, certain chlorinated compounds (e.g. PCB, CFCs), components, and parts containing heavy metals or brominated flame retardants, printed circuit boards, cathode ray tubes (CRTs), and LCD screens [7]. After disassembly and mechanical sorting, material fractions (e.g. metals, plastics, and glass) are delivered to recycling or reprocessing plants for further utilization, while materials and components requiring selective treatment are directed to special treatment plants or for final disposal [31]. The main stages of the WEEE recovery system in Sweden are presented in Figure 8.

El-Kretsen makes contracts with transportation companies and treatment plants (a recycling service provider) based on five different categories: (1) assorted electrical and electronic goods, (2) large white goods, (3) fridges and freezers, (4) batteries, and (5) lighting. Depending on the segments, El-Kretsen has split Sweden into 1 to 14 different collection areas of various service providers based on volume, logistics costs, and location of preprocessing [31, 33]. For instance, in 2012, there were five collection areas for fridges and freezers and ten areas for large white goods while a single collection area of lighting equipment was extended over the whole country [31].

The procurement of recycling services is conducted through an open tender procedure. All tenders who met the environmental and quality requirements had an opportunity to take part in the procurement process. The transport procurement is implemented in the same manner and the transportation volume of a collecting area is divided between two to three transportation companies so that transportation routes are optimised. Each transport supplier is specialised to deal with a particular category and region. A web-based system was introduced already in 2007 to disseminate and cover information. Transporters have access to stock reports that the collection facilities have submitted. The transporters plan their shipments and use handheld computers to report back. The recyclers can then see when the transporters are planning to deliver the WEEE. The cash flow between ElKretsen and a pretreatment service provider is based on the material value. The treatment service provider "buys" the WEEE from El-Kretsen; although they pay only if they can derive a profit from it. In the case of large white goods and television sets, when the value is negative, EL-Kretsen pays to the treatment service provider $[31,33]$.

El-Kretsen is taking care of WEEE recycling, but it is not involved with the reuse of remanufacture. Currently, there is no formal second hand market for the products collected through the El-Kretsen's system [32]. However, the organisations responsible for collection points may occasionally take care of reuse [33]. Moreover, some recycling centres have special containers, where visitors can place functional electronics [32]. The basic feature of the Swedish system is the efficiency of materials flows through centralized recycling operations and optimised transportation. Large companies dominate the recycling business and, according to Lehtinen et al. [33], social enterprises have a very small role in recycling in Sweden; El-Kretsen supplied only 5\% of its volume from social companies in 2007.

\section{WEEE Recovery in Norway}

6.1. National WEEE Legislation in Norway. Norway has a long history in regulating WEEE. It was one of the first countries in the world that regulated WEEE in 1998 and, in addition, it started to run the WEEE recovery system in 1999. Even though Norway is not an EU member state, it is obliged to implement EU Directives in its national legislation by the EEA (European Economic Area) agreement. Therefore, the Norwegian legislation related to WEEE (Chapter 1 of the Waste Regulation) was revised to comply with the WEEE Directive in June 1, 2006. At the same time, a national EEE register, called EE-Registeret, owned by the Norwegian Environment Agency, was established. The register comprises of an administrative and a web-based module, providing overview of all imports and exports of EEE and WEEE from all producers and importers. The Norwegian WEEE legislation has also been amended; the latest amendment was implemented as recent as August 22, 2013. 


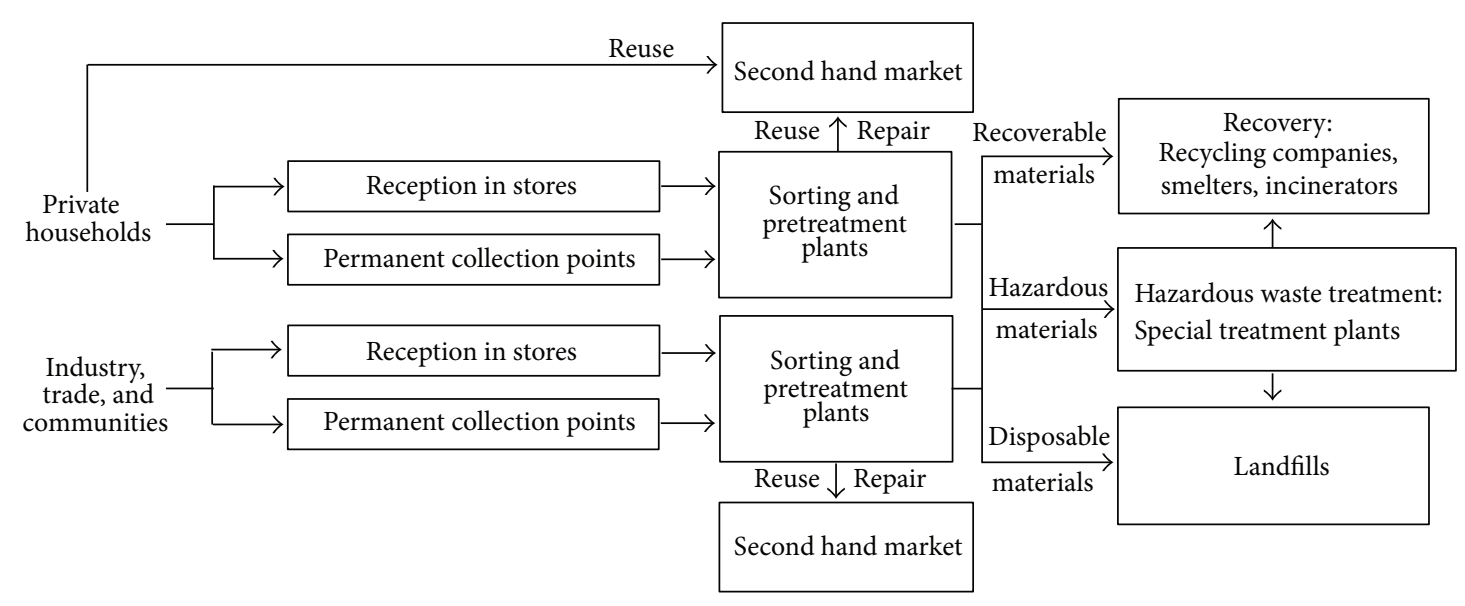

FIgURE 9: The main stages of the WEEE recovery system in Norway based on $[37,39]$.

The current definition of WEEE in Norwegian legislation is broader than in EU. In addition to ten categories established according to the WEEE Directive 2002/96/EC, the Norwegian legislation also includes the following four extra categories comprising WEEE mainly from industry and business [37]:

(11) automatic machines for selling beverages, food, cash points, and equipment delivering automatic products,

(12) cables, wires,

(13) electronic equipment (passenger and freight lifts, moving staircases, and winches),

(14) mounted rigid equipment for heating, air-conditioning, and ventilation.

6.2. The Norwegian WEEE Recovery Infrastructure. At the moment, there are five collectively financed take-back companies, Elretur AS, Elsirk AS, ERP Norge AS, RENAS AS, and Eurovironment AS, registered and authorized by the Norwegian Environment Agency. Two of these companies, Elretur and RENAS, are nonprofit companies owned by the Electric and Electronic Industry and Business Sector and they have been in the business for more than 10 years. Elretur has concentrated on WEEE from households and RENAS on WEEE from industry [37]. Take-back companies are required to ensure free collection from enterprises, distributors, and municipalities collecting WEEE and confirming that the collected WEEE is treated pursuant to the requirements of the Norwegian waste regulation. Further, WEEE collection and receipt should be in line with the geographical areas of Norway where member EEE companies are located, or where they have previously sold or supplied EEE. In addition, the proportion of the total collected WEEE has to be in correspondence with the members' share of the total supply of goods. Currently, more than 4800 companies have joined the collectively financed take-back companies while there are no individually financed take-back companies in Norway [38].

In the Norwegian WEEE system, WEEE collection is organized on a municipal level by intermunicipal waste companies or by stores. The material flows of WEEE in
Norway are outlined in Figure 9. The Norwegian WEEE treatment procedure follows the outline of Finnish and Swedish practices to achieve high material recovery rates and to fulfil the requirements of special treatment of hazardous substances.

Despite the good functionality of the system, WEEE resources are not utilized optimally because most of the treatment facilities are located near Oslo, the capital in the southern part of the country, causing long and demanding transportation conditions for WEEE. Therefore, some unexplored potentials for new business and reverse chain management of WEEE still exists [37].

\section{Comparative Analysis of the Nordic WEEE Recovery Systems}

7.1. Realisations of WEEE Recovery Systems. As pioneers of WEEE management, the Swedish and Norwegian recovery systems were already in operation when the Finnish system was initiated due to the WEEE Directive. In the planning phase of the Finnish WEEE recovery system, the Swedish and Norwegian systems were benchmarked by Finns to identify the factors of a success. Therefore, the Nordic recovery systems have several similarities. In all three countries, for example, the WEEE management system is financed by a fee included in the price of EEE [7, 40]. Moreover, producer responsibility has been launched through collective systems, where the representatives of foreign and domestic producers have transferred responsibility over discarded electronics to producers associations and onwards to service providers. Further, WEEE collection is organized mainly on a municipal level and municipalities have a significant role in arranging and maintaining several hundreds of permanent collection points around the countries.

In addition to similarities, there are also some fundamental differences in the Nordic recovery systems. The main difference is the number of organizations involved with WEEE management. In Finland and Norway, several collectively financed take-back companies manage the collection and recycling operations while only one organization (ElKretsen) services all producers and manufacturers in Sweden. 
TABLE 4: The overview of national WEEE recovery systems in Finland, Sweden, and Norway.

\begin{tabular}{|c|c|c|c|}
\hline Characteristic & Finland & Sweden & Norway \\
\hline Legislation & $\begin{array}{l}\text { Directive 2002/96/EC } \\
\text { implemented in 2004, no } \\
\text { exemptions. } \\
\text { Finnish Waste Act revised in } \\
2011 \text { and amended in } 2014 \text { to } \\
\text { comply with the Directive } \\
\text { 2012/19/EU [41]. }\end{array}$ & $\begin{array}{l}\text { Law of producer } \\
\text { responsibility for EE } \\
\text { products into force 2001, } \\
\text { revised in } 2005 \text { to comply } \\
\text { with the Directive } \\
\text { 2002/96/EC. Amended in } \\
2014 \text { to comply with the } \\
\text { Directive 2012/19/EU [42]. }\end{array}$ & $\begin{array}{l}\text { Law of scrapped EE } \\
\text { products into force } 1998, \\
\text { amended in } 2006 \text { and } 2013 \\
\text { to comply to the } \\
\text { requirements of the } \\
\text { Directives } 2002 / 96 / E C \text { and } \\
2012 / 19 / E U \text {. The definition } \\
\text { of WEEE is broader than in } \\
\text { EU [43]. }\end{array}$ \\
\hline Financing method & $\begin{array}{l}\text { Recycling fee included in the } \\
\text { EEE prices [44]. }\end{array}$ & $\begin{array}{l}\text { Recycling fee included to } \\
\text { the EEE prices [42]. }\end{array}$ & $\begin{array}{l}\text { Recycling fee included to } \\
\text { the EEE prices [43]. }\end{array}$ \\
\hline $\begin{array}{l}\text { Launch of the } \\
\text { separate collection }\end{array}$ & $\begin{array}{l}\text { 2004, in consequence of the } \\
\text { WEEE Directive [13]. }\end{array}$ & $2002[32]$ & $1999[40]$ \\
\hline Operators & $\begin{array}{l}5 \text { producer associations [45]: } \\
\text { (i) FLIP ry, } \\
\text { (ii) ICT-tuottajaosuuskunta, } \\
\text { (iii) SELT ry, } \\
\text { (iv) SERTY ry, } \\
\text { (v) ERP Finland ry } \\
\text { (Elker Ltd. is founded by Flip, } \\
\text { ICT and SELT). }\end{array}$ & $\begin{array}{l}2 \text { collective take-back and } \\
\text { financing systems [32]: } \\
\text { (i) El-Kretsen (municipal } \\
\text { collection points and B2B } \\
\text { collection), } \\
\text { (ii) EÅF (in-store } \\
\text { collection). }\end{array}$ & $\begin{array}{l}5 \text { collectively financed } \\
\text { take-back companies [37]: } \\
\text { (i) Elretur AS (only C2B), } \\
\text { (ii) RENAS AS (only B2B), } \\
\text { (iii) Elsirk AS, } \\
\text { (iv) ERP Norge AS, } \\
\text { (v) Eurovironment AS. }\end{array}$ \\
\hline $\begin{array}{l}\text { Collected amounts } \\
\text { of WEEE }\end{array}$ & $\begin{array}{l}9.5 \mathrm{~kg} / \text { inhab./year (in 2010) } \\
{[46] .}\end{array}$ & $\begin{array}{l}17.2 \mathrm{~kg} / \text { inhab./year } \\
\text { (in 2010) [46]. }\end{array}$ & $\begin{array}{l}28.0 \mathrm{~kg} / \text { inhab./year } \\
(22.0 \mathrm{~kg} / \text { inhab./year in } \\
\text { compliance with Directive } \\
\text { 2002/96/EC) (in 2010), } \\
{[40,46] .}\end{array}$ \\
\hline
\end{tabular}

Therefore, the Finnish and Norwegian systems are regarded as more fragmented. Another main difference is related to the recovery routes of WEEE. In the Finnish system, the recovery route depends on the brand but not the source (from private consumer or from business) and, therefore, all WEEE of a certain producer is treated at the same pretreatment station notwithstanding the type of the WEEE. However, in the Norwegian case, WEEE collected from private consumers follows a different treatment route than those collected from business. The basic characteristics of the national WEEE recovery systems in the Nordic countries are overviewed in Table 4.

7.2. Amounts of Collected WEEE. Separate collection is a precondition of ensuring the recycling of WEEE. According to Directive 2002/96/EC, a separate collection of WEEE had to be arranged since August 13, 2005, a general collection target (4 kg/inhab./year) and treatment requirements, recovery, and recycling rates (up to 80 and $75 \mathrm{w} \%$ ) had to be realised by December 31, $2006[3,7]$.

All three Nordic countries have succeeded to set up a functioning WEEE recovery infrastructure. Norway and Sweden had national WEEE legislation and operational recovery systems even prior the EU legislation, and Finland has enacted the WEEE Directive and built a functional infrastructure in a relatively short time. In all these countries, the collection requirement of $4 \mathrm{~kg} /$ inhab./year has clearly been exceeded (see Figure 10) and, in addition, good recovery percentages have been achieved.
As seen from Figure 10, Norway has the highest amounts of collected WEEE per capita. Around one-fifth of the collected WEEE in Norway consists of various automatic machines, cables, and wires, as well as large electronic equipment for conveying people, commodities, or air, which are included in the national legislation but excluded from the WEEE Directive. Even if that portion is not taken into consideration, Norway still has the most effective collection of the three countries with over $25 \mathrm{~kg} /$ inhab./year. Sweden achieved and maintained a steady annual level of $15 \mathrm{~kg} /$ inhab./year since 2007. As for Finland, the WEEE recovery network was not set up until 2006 and, subsequently, the per capita collection amounts are still substantially lower level than in Norway or Sweden. However, based on the data from Statistics Finland, a clear improvement in collection amounts occurred in recent years.

When the collection amounts of WEEE in the Nordic countries are considered as total tonnages, the highest quantities have been gathered in Sweden. The annual tonnages of WEEE collected in Finland, Sweden, and Norway in 2006-2012 are illustrated in Figure 11. Collected WEEE amounts have been categorized by the source and, in the case of Norway, also by the definition of WEEE according to the official EU statistics. Up until 2010, the Norwegian statistics also included equipment excluded from the WEEE Directive. Since 2011, only the total tonnages of collected WEEE are included in Figure 11 because national authorities do not provide statistics on the types of WEEE. 


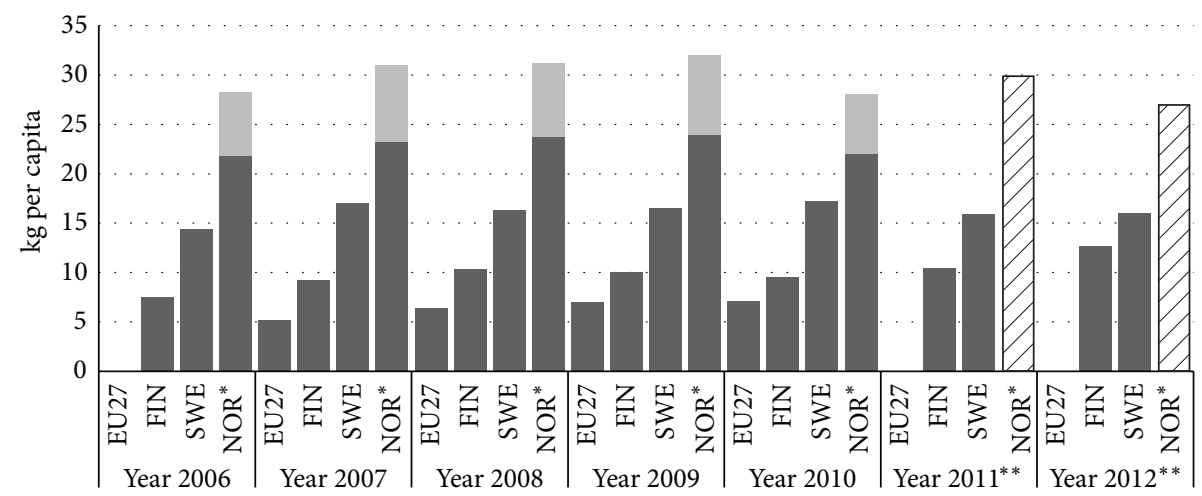

- In compliance with the WEEE Directive

Excluded from the WEEE Directive

$\square$ Total amount of collected WEEE

** Data from national statistical offices

* National definition is broader than in EU

FIGURE 10: Amounts of collected WEEE per capita in Finland, Sweden, and Norway in 2006-2012 compared to the average of EU 27 [40, 4649].

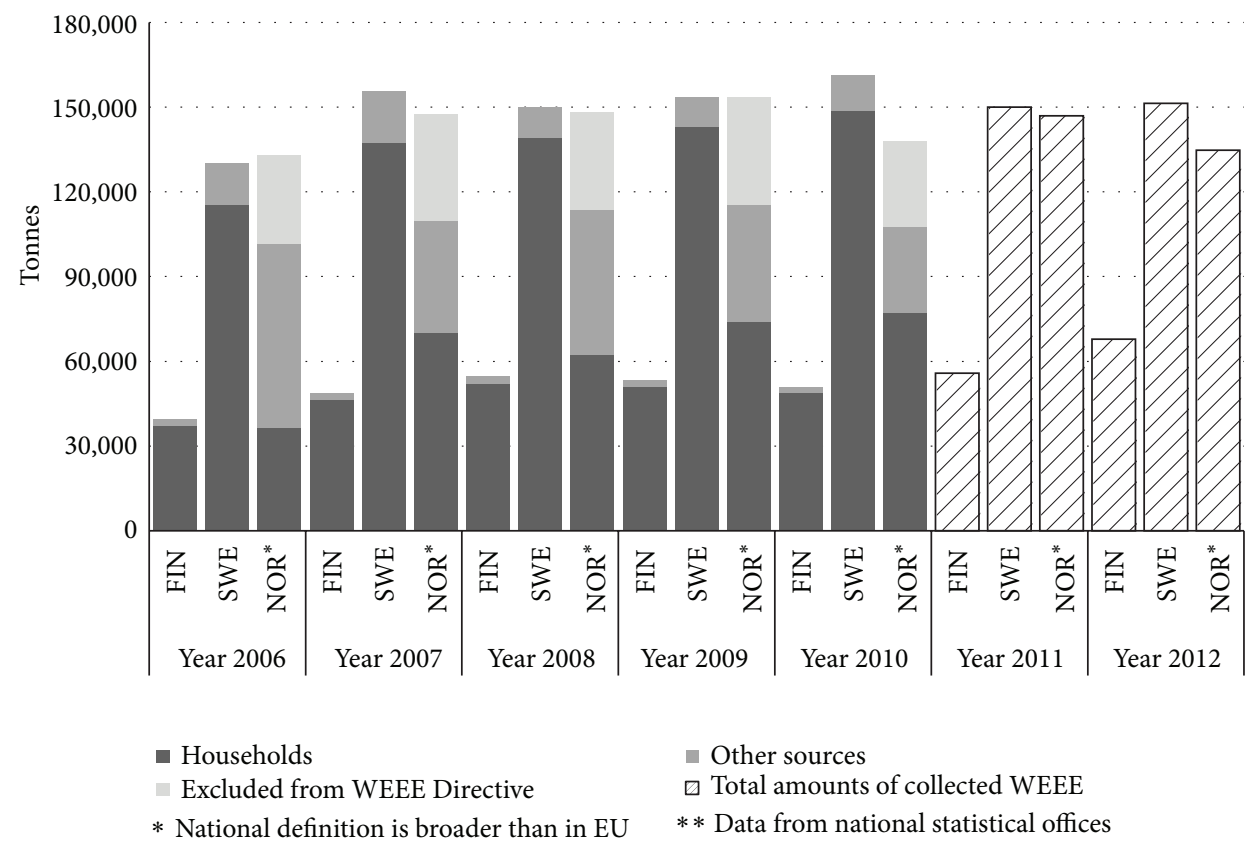

FIgURE 11: Amounts of collected WEEE from households and other sources in Finland, Sweden, and Norway in 2006-2012 [40, 46-49].

Despite the good annual WEEE collection and treatment rates in the Nordic countries, the tendency of collected WEEE amounts has recently turned slightly down in Norway and Sweden, as seen from Figures 10 and 11, while total tonnages of collected WEEE in Finland is still increasing. There is no absolute reason for this phenomenon but it seems that the Norwegian and Swedish WEEE recovery systems have reached a certain saturation point, while the Finnish system is still in its growth phase. It is also generally accepted that the prolonged instability of European and world economies has also weakened people's eagerness to replace functional devices by newer models. Bernstad et al. [34] have suggested that the trend towards smaller and more light-weight electronic devices may also have an impact on the decreasing tendency. Moreover, a Finnish study of [20] pointed out that leakage outside the official WEEE recovery system has also increased due to the continuously rising metal prices.

7.3. Compliance with Recovery and Recycling Targets of the WEEE Directive. The first official data from Finnish producer registration system from 2006 were reported to the $\mathrm{EU}$ in June 2008. According to the EU statistics, a total of 39,678 tonnes or some $7.5 \mathrm{~kg} /$ inhab./year of WEEE were collected separately in Finland in the very first year after the implementation of the WEEE recovery system. Four years later, in 2010 (see Table 5), the total amount of collected WEEE in Finland had increased by around 30\% to 50,867 tonnes 
TABLE 5: Amounts of collected WEEE and achieved recovery and recycling rates in Finland, Sweden, and Norway in 2010 in compliance with the Directive 2002/96/EC [46].

\begin{tabular}{|c|c|c|c|c|c|}
\hline & Categories & Amount [tonnes] & Portion [w\%] & Recovery/target [\%] & Reuse and recycling/targets [\%] \\
\hline \multirow{11}{*}{$\begin{array}{r}1 \\
2 \\
3 \\
4 \\
5 \\
\text { Finland } 6 \\
7 \\
8 \\
9 \\
10\end{array}$} & Large household appliances & 27,698 & 54.5 & $93 / 80$ & $88 / 75$ \\
\hline & Small household appliances & 1320 & 2.6 & $84 / 70$ & $82 / 50$ \\
\hline & IT and telecom equipment & 8034 & 15.8 & $92 / 75$ & $92 / 65$ \\
\hline & Consumer electronics & 12,117 & 23.8 & $90 / 75$ & $88 / 65$ \\
\hline & Lighting equipment & 961 & 1.9 & $91 / 70$ & $86 / 50$ \\
\hline & Electrical and electronic tools & 276 & 0.5 & $94 / 70$ & $98 / 50$ \\
\hline & Toys, leisure, and sports devices & 99 & 0.2 & $84 / 70$ & $82 / 50$ \\
\hline & Medical devices & 53 & 0.1 & $75 /-$ & $75 /-$ \\
\hline & Monitoring and control instruments & 119 & 0.2 & $78 / 70$ & $76 / 50$ \\
\hline & Automatic dispensers & 189 & 0.4 & $98 / 80$ & $78 / 75$ \\
\hline & Total/average & 50,867 & 100 & 91.5 & 88.5 \\
\hline \multirow{11}{*}{$\begin{array}{r}1 \\
2 \\
3 \\
4 \\
5 \\
\text { Sweden } 6 \\
7 \\
8 \\
9 \\
10\end{array}$} & Large household appliances & 75,341 & 46.7 & $91 / 80$ & $86 / 75$ \\
\hline & Small household appliances & 8959 & 5.6 & $91 / 70$ & $74 / 50$ \\
\hline & IT and telecom equipment & 31,756 & 19.7 & $92 / 75$ & $84 / 65$ \\
\hline & Consumer electronics & 37,809 & 23.4 & $94 / 75$ & $82 / 65$ \\
\hline & Lighting equipment & 4396 & 2.7 & $94 / 70$ & $93 / 50$ \\
\hline & Electrical and electronic tools & 1531 & 0.9 & $82 / 70$ & $71 / 50$ \\
\hline & Toys, leisure, and sports devices & 697 & 0.4 & $82 / 70$ & $70 / 50$ \\
\hline & Medical devices & 519 & 0.3 & $92 /-$ & $86 /-$ \\
\hline & Monitoring and control instruments & 91 & 0.1 & $92 / 70$ & $82 / 50$ \\
\hline & Automatic dispensers & 345 & 0.2 & $73 / 80$ & $68 / 75$ \\
\hline & Total/average & 161,444 & 100 & 91.8 & 83.9 \\
\hline \multirow{11}{*}{$\begin{array}{r}1 \\
2 \\
3 \\
4 \\
5 \\
\text { Norway } 6 \\
7 \\
8 \\
9 \\
10\end{array}$} & Large household appliances & 44,031 & 40.9 & $94 / 80$ & $84 / 75$ \\
\hline & Small household appliances & 7,592 & 7.0 & $89 / 70$ & $79 / 50$ \\
\hline & IT and telecom equipment & 16,496 & 15.3 & $87 / 75$ & $79 / 65$ \\
\hline & Consumer electronics & 18,479 & 17.2 & $84 / 75$ & $76 / 65$ \\
\hline & Lighting equipment & 7,760 & 7.2 & $90 / 70$ & $86 / 50$ \\
\hline & Electrical and electronic tools & 10,009 & 9.3 & $88 / 70$ & $85 / 50$ \\
\hline & Toys, leisure, and sports devices & 479 & 0.4 & $81 / 70$ & $74 / 50$ \\
\hline & Medical devices & 584 & 0.5 & $86 /-$ & $79 /-$ \\
\hline & Monitoring and control instruments & 2,131 & 2.0 & $88 / 70$ & $83 / 50$ \\
\hline & Automatic dispensers & 206 & 0.2 & $86 / 80$ & $69 / 75$ \\
\hline & Total/average & 107,767 & 100 & 89.9 & 81.5 \\
\hline
\end{tabular}

or approximately $9.5 \mathrm{~kg} /$ inhab./year. Meanwhile, a total of 161,444 tonnes of WEEE (approximately $17.2 \mathrm{~kg} /$ inhab./year) was collected in Sweden and 107,767 tonnes (approximately $22 \mathrm{~kg} /$ inhab./year) in Norway in compliance with the WEEE Directive. Compositional breakdowns and amounts of the collected WEEE in 2010 are represented in Table 5. According to European statistics, the target rates set down in the WEEE Directive for reuse, recycling, and recovery of WEEE were fulfilled in every category. The total rates of recovery and recycling in Finland were increased, from those in 2006, to $91.5 \%$ for recovery and $88.1 \%$ for material recycling, while the rate of reuse reduced to $0.4 \%$ in 2010 . The total rates in Sweden and Norway were equivalent to that in Finland: $91.8 \%$ and $89.9 \%$ for recovery and $83.8 \%$ and $81.1 \%$ for recycling, respectively. Further, reuse rates remained at $0.1 \%$ in Sweden and $0.4 \%$ in Norway [46].
Based on the EU statistics, the compositional breakdown of WEEE collected in Norway differs substantially from WEEE collected in Finland and Sweden (see Table 5). In Norway, the amounts of collected large household appliances (40.9 w\%) were lower than those in Sweden $(46.7 \mathrm{w} \%)$ and especially in Finland (54.5 w\%), and also the portion of collected consumer electronics (17.2 w\%) remained substantially lower than in Finland and Sweden (23.8 w\% and $23.4 \mathrm{w} \%)$. However, portions of lighting equipment $(7.2 \mathrm{w} \%)$ and $\mathrm{EE}$ tools $(9.3 \mathrm{w} \%)$ were substantially higher in Norway than in Finland $(1.9 \mathrm{w} \%$ and $0.5 \mathrm{w} \%)$ and Sweden $(2.7 \mathrm{w} \%$ and $0.9 \mathrm{w} \%)$. Also monitoring and control instruments were collected tenfold in Norway compared to Finland and Sweden [46].

A divergent breakdown of the Norwegian WEEE is due to its origin; a considerably higher amount of WEEE is 
collected from industry in Norway than in Finland and Sweden. According to EU statistics, a total of 30529 tonnes or some $28.3 \%$ of B2B WEEE were collected in Norway in compliance with the WEEE Directive in 2010, while its proportion remained 7.8\% (12,549 tonnes) in Sweden and less than 4\% (2010 tonnes) in Finland [46]. As a conclusion, it seems that specialised operators and/or parallel routes for WEEE from business improve the productivity of the WEEE recovery system. On the other hand, the amounts of collected B2B WEEE in Sweden and Finland may remain at a lower level than in Norway because the WEEE Directive has been implemented to focus on WEEE only from private consumers and households. In consequence, all B2B WEEE, even if collected and treated in compliance with the Directive, has not necessarily been reported to the official EU statistics due to lack of reporting obligations of member states. Some uncertainty about EU statistics arises also from the possibility of mixing $\mathrm{C} 2 \mathrm{~B}$ and $\mathrm{B} 2 \mathrm{~B}$ WEEE flows at the collection stage. For instance, B2B collection points of Finnish WEEE recovery system are available also to private consumers and retailers when returning larger batches of WEEE regardless of their origin.

\section{Best Practices of Nordic WEEE Recovery Systems}

The primary goal of the European WEEE legislation is to prevent waste generation and to promote reuse, recycling, and other forms of recovery of such waste. To fulfil these requirements, comprehensive collection WEEE networks have been built in the Nordic countries. In addition to hundreds of permanent collection points situated in recycling centres and shops nationwide, more allocated options, such as property-close and mobile collection have also been deployed to ensure a reasonable opportunity to return discarded EEE for recovery. From a quantitative point of view, the most effective recovery system has been built in Norway as the annual collected amount of WEEE, in compliance with national definition of WEEE, reached $30 \mathrm{~kg}$ per capita already in 2007 and, since then, it has steadily remained above $25 \mathrm{~kg}$ per capita despite the trend towards smaller and more light-weight electronics $[34,40]$. In the context of the EU WEEE legislation, annual collection amounts in Norway vary between 22 and $24 \mathrm{~kg}$ per capita, from which $13-16 \mathrm{~kg}$ have been collected from households [46]. Also Sweden and Finland have achieved top collection rates at the European level. As can be seen in Figure 12, only Denmark matches the efficiency of the Swedish and Norwegian systems. Even Finland has managed to overcome Germany and Austria in recovery efficiency, even though these countries are typically very advanced in their waste management practices. At this point it is also worthwhile to look back at Figure 4 to remind the tremendous difference in population densities of the reviewed Nordic countries and the rest of Europe.

A uniform WEEE collection target of $4 \mathrm{~kg} /$ inhab./year for whole EU has raised discussion in member states, since volumes of EE devices put on the market annually vary substantially in European countries. Therefore, the more demanding and gradually evolved, specific collection targets for each member state are included in the recast Directive. From 2016 onwards, the annual collection target will be defined as the ratio between the collected amount and the average weight of EEE put in the market in the three preceding years. The collection target is set at $45 \%$ in 2016 and will rise to $65 \%$ in 2019 [7]. When current collection amounts of the Nordic countries are compared to upcoming requirements, it can be said that Sweden and Norway have already achieved the $45 \%$ target in 2010 and Sweden even exceeded the $65 \%$ collection target. Finland reached $30 \%$ in 2010 and, therefore, WEEE collection in Finland will still have to be improved in next few years [50].

The key motives behind the Nordic WEEE recovery systems are not only national and EU legislations but also market value of the materials contained in WEEE. However, long transportation distances, especially in the northernmost parts of the countries, bring challenges to managing the WEEE recovery systems effectively. The most competent recovery system from the material efficiency point of view is implemented in Sweden. In the Swedish system, there is no formal second hand market for the products collected through the system. Therefore, producer responsibility organizations are responsible only for the management of WEEE recycling, which can then be optimized from an efficient material flow point of view. The other key issue is the one dominant service provider for the whole country. By controlling the whole WEEE recovery chain, El-Kretsen is able to offer practical and cost-effective solutions and optimized transportation from collection points to centralised treatment plants. Lee and Sundin [32] argued that the standardised system at the national level also provides clear roles and an efficient way for all stakeholders to operate. Increased understanding and satisfaction amongst stakeholders in turn results in an improved efficiency of the Swedish WEEE recovery system.

The WEEE legislation highlights that private consumers need to be able to dispose WEEE through the official system without any charge, while industries, educational institutes, and communities may have to pay for the use of it. Currently, only small amounts of WEEE from industry are reported as collected in compliance with the WEEE Directive in EU member states, including Finland and Sweden. However, according to recent studies of Huisman et al. [51] and Peagam et al. [52], a remarkable amount of B2B WEEE is properly collected but still not reported due to the organisations' practices to dispose their $\mathrm{B} 2 \mathrm{~B}$ WEEE through contractors or informal arrangements. This means that complementary recycling streams for $\mathrm{B} 2 \mathrm{~B}$ WEEE exist in parallel with the official WEEE recovery system in EU $[51,52]$. The feature of the Norwegian system, where WEEE collected from private consumers follows a different treatment route than those collected from business, enables more flexibility to select optimal recovery routes and also promotes the reuse of $\mathrm{B} 2 \mathrm{~B}$ devices improving the efficiency of the recovery system. Further, as a nonmember of the EU, in Norway all EEE products imported and exported are recorded, which enables a better control of EEE and WEEE flows and more accurate calculations of WEEE amounts leaking outside the recovery 

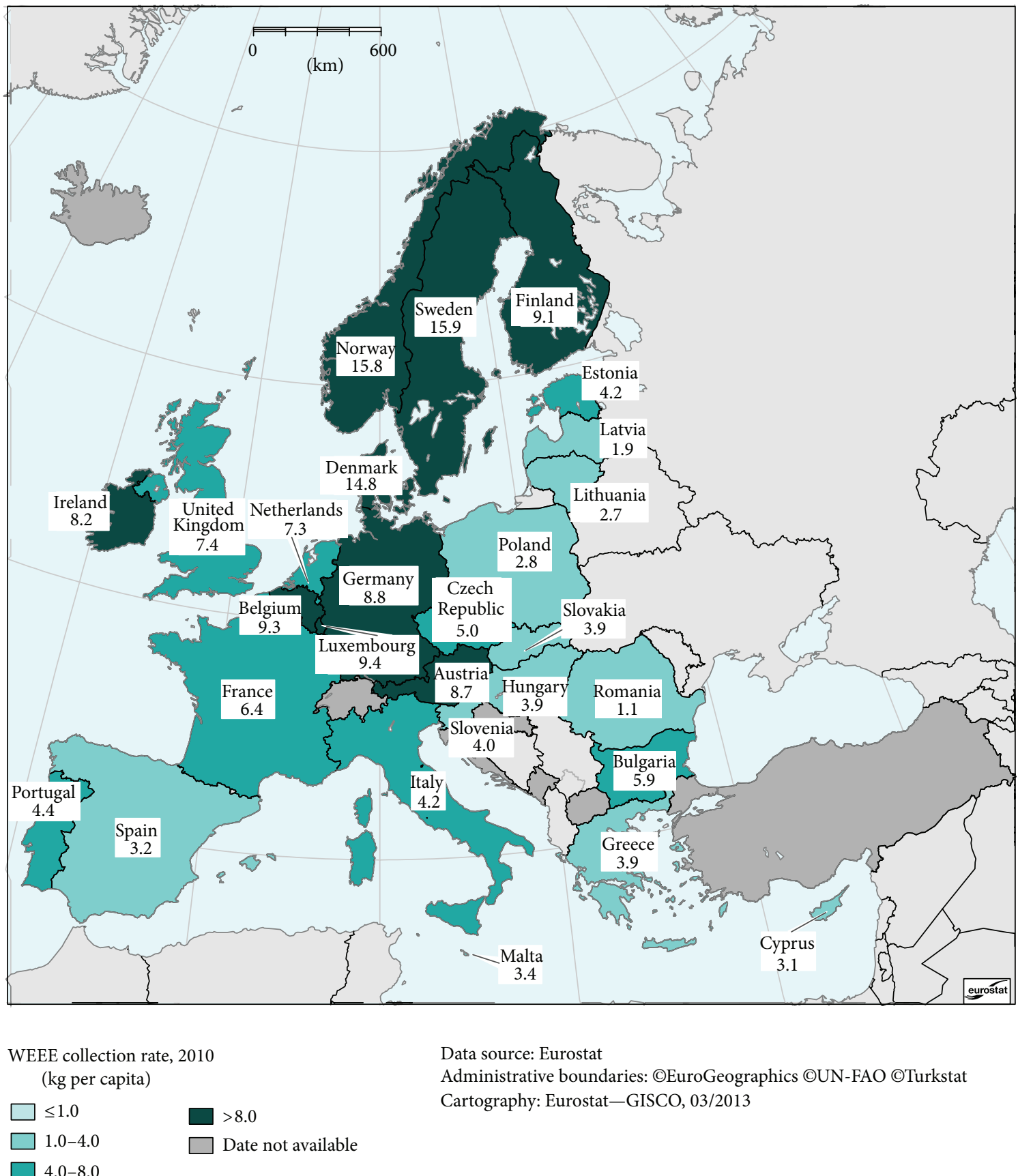

Data source: Eurostat

Administrative boundaries: @EuroGeographics @UN-FAO @Turkstat Cartography: Eurostat-GISCO, 03/2013

$4.0-8.0$

FIGURE 12: WEEE collection rates from households in the compliance of the WEEE Directive in 2010 [46].

system. Therefore, the Norwegian system as a whole can be managed more efficiently than the systems in Finland and Sweden.

Reasonable, nationwide possibilities to return EOL devices and an efficient management of the WEEE recycling system are still not enough for creating a sustainable WEEE recovery system; the level of consumers' understanding of the importance of separate WEEE collection and their behaviour regarding the return of EOL devices to collection points have also a significant influence on the effectiveness of WEEE recovery. Scandinavians are typically highly aware of environmental issues and, therefore, also willing to take advantage of established WEEE recovery systems. Therefore, it can be said that one of the largest strengths of the WEEE recovery systems in all three Nordic countries is a strong civic support of environmental protection.

\section{Conclusions}

The purpose of this paper was to provide a comprehensive overview of the European WEEE Directive and its implementation in the Nordic countries. The WEEE recovery systems in Finland, Sweden, and Norway are evaluated from the point of resource efficiency to identify successful and efficient 
factors as well as best practices. Based on this study, it can be concluded that the national implementations of the WEEE Directive and development of WEEE recovery infrastructure have succeeded in the Nordic countries. In addition to Norway and Sweden as global frontrunners of WEEE management, Finland also has enacted the legislative basis and has built a functional infrastructure successfully in a relatively short time after the implementation of the WEEE legislation in the EU. The collection requirements of the Directive ( $4 \mathrm{~kg} /$ inhab./year) have clearly been exceeded and excellent recovery percentages of WEEE have been achieved in all three countries. Since 2007, the WEEE collection rates in Finland, Sweden, and Norway have exceeded $9 \mathrm{~kg} /$ inhab./year despite their sparse populations, standing as the top five in Europe. Therefore, we believe that the WEEE collection systems as established in the Nordic countries have evident advantages, which can be considered by countries implementing national WEEE legislation or setting up WEEE collection networks.

In addition to the efficient management of WEEE recovery systems, the level of consumers' understanding of the importance of separate WEEE collection and their behaviour regarding the return of EOL devices to collection points influences significantly the effectiveness of WEEE recovery. The Swedish and Norwegian experiences with long history of WEEE recovery prove that raising consumer awareness leads to environmentally sound behaviour and improved WEEE recovery efficiency. However, more information and communication is still needed to fully realize the potential of WEEE recovery and to establish sustainable WEEE recovery systems.

\section{Conflict of Interests}

The authors declare that there are no conflicts of interests regarding the publication of this paper.

\section{Acknowledgment}

The financial support of the Thule Institute's Doctoral Program at the University of Oulu is gratefully acknowledged.

\section{References}

[1] European Commission, "Proposal for WEEE and RoHS Directives," COM 347 final, 2000.

[2] European Commission, "Report on critical raw materials for the EU," Report of the Ad hoc Working Group on Defining Critical Raw Material, European Commission, Brussel, Belgium, 2014, http://ec.europa.eu/enterprise/policies/raw-materials/files/docs/crm-report-on-critical-raw-materials_en.pdf.

[3] European Commission, "Directive 2002/96/EC of the European Parliament and of the Council of 27 January 2003 on Waste Electrical and Electronic Equipment," Official Journal L 37, 2003.

[4] European Parliament, "The principle of subsidiarity," 2012, http://circa.europa.eu/irc/opoce/fact_sheets/info/data/how/ characteristics/article_7148_en.htm.

[5] European Commission, "Staff working paper," Tech. Rep. SEC/ 2008/2933, 2008.
[6] M. Banti, "The new WEEE Directive and the main challenges under this new regime," in Proceedings of the ISWA Beacon Conference: Optimising Collection and Recycling of WEEE, Düsseldorf, Germany, November 2013.

[7] European Commission, "Directive 2012/19/EU of the European Parliament and of the Council of 4 July 2012 on Waste Electrical and Electronic Equipment (WEEE) Text with EEA relevance," Official Journal L197, 2012.

[8] Association of Finnish Local and Regional Authorities, "Population statistics," 2014 (Finnish), http://www.kunnat.net/fi/ tietopankit/tilastot/vaestotietoja/Sivut/default.aspx.

[9] Statistics Sweden, "Population statistics," 2014 (Swedish), http://www.scb.se/sv_/Hitta-statistik/Statistik-efter-amne/Befolkning/Befolkningens-sammansattning/Befolkningsstatistik/ 25788/25795/.

[10] Statistics Norway, "Population," 2014, http://www.ssb.no/en/ befolkning/statistikker/folkemengde/aar/2014-02-20?fane= tabell\#content.

[11] Eurostat, "Population statistics," 2014, http://epp.eurostat.ec .europa.eu/portal/page/portal/population/introduction.

[12] Nordic Centre for Spatial Development (Nordregio), "Population density 2012," 2014, http://www.nordregio.se/en/MapsGraphs/.

[13] J. Ylä-Mella, K. Poikela, U. Lehtinen, R. L. Keiski, and E. Pongrácz, "Implementation of waste electrical and electronic equipment directive in Finland: evaluation of the collection network and challenges of the effective WEEE management," Resources, Conservation and Recycling, vol. 86, pp. 38-46, 2014.

[14] S. A. Lonn, J. A. Stuart, and A. Losada, "How collection methods and e-commerce impact product arrival rates to electronics return, reuse, and recycling centers," in Proceeding of the IEEE International Symposium on Electronics and the Environment, pp. 228-233, San Francisco, Calif, USA, May 2002.

[15] N. Truttmann and H. Rechberger, "Contribution to resource conservation by reuse of electrical and electronic household appliances," Resources, Conservation and Recycling, vol. 48, no. 3, pp. 249-262, 2006.

[16] M. Savage, S. Ogilvie, J. Slezak, and E. Artim, Implementation of Waste Electric and Electronic Equipment Directive in EU, European Commission, Directorate-General Joint Research Centre, Institute for Prospective Technological Studies, Luxemburg, Luxemburg, 2006, http://ftp.jrc.es/EURdoc/eur22231en.pdf.

[17] United Nations Environmental Programme, "E-waste Volume III-WEEE/e-waste 'Take back system," Division of Technology, Industry and Economics, International Environmental Technology Centre, P. 148, 2013, http://www.unep.org/ietc/ InformationResources/Publications/E-wasteManual3/tabid/ 130121/Default.aspx.

[18] P. Chancerel, Substance flow analysis of the recycling of small waste electrical and electronic equipment-an assessment of the recovery of gold and palladium [Ph.D. thesis], Technical University of Berlin, Berlin, Germany, 2010.

[19] P. Tanskanen, "Management and recycling of electronic waste," Acta Materialia, vol. 61, no. 3, pp. 1001-1011, 2013.

[20] A. Toppila, Waste flows in Finnish producer responsibility system-case WEEE and portable batteries and accumulators [M.S. thesis], University of Jyväskylä, Jyväskylä, Finland, 2011, (Finnish).

[21] H.-Y. Kang and J. M. Schoenung, "Electronic waste recycling: a review of U.S. infrastructure and technology options," Resources, Conservation and Recycling, vol. 45, no. 4, pp. 368400, 2005. 
[22] Ministry of the Environment in Finland, "Waste Act 646/2011", 2014, http://finlex.fi/.

[23] SERTY, “Data from EEE distributors' register," 2014.

[24] E. Oyj, "Waste treatment," 2014, http://www.ekokem.fi/en/ waste-services/waste-treatment.

[25] J. Huisman, F. Magalini, R. Kuehr et al., 2008 Review of Directive 2002/96 on Waste Electrical and Electronic Equipment (WEEE), United Nations University, Bonn, Germany, 2007.

[26] Y.-C. Jang and M. Kim, "Management of used \& end-of-life mobile phones in Korea: a review," Resources, Conservation and Recycling, vol. 55, no. 1, pp. 11-19, 2010.

[27] F. W. Melissen, "Redesigning a collection system for "small" consumer electronics," Waste Management, vol. 26, no. 11, pp. 1212-1221, 2006.

[28] M. Polák and L. Drápalová, "Estimation of end of life mobile phones generation: the case study of the Czech Republic," Waste Management, vol. 32, no. 8, pp. 1583-1591, 2012.

[29] P. Tanskanen and E. Butler, "Mobile phone take back learning's from various initiatives," in Proceedings of the IEEE International Symposium on Electronics \& the Environment (ISEE '07), pp. 206-209, Orlando, Fla, USA, May 2007.

[30] P. Tanskanen, "Electronics waste: recycling of mobile phones," in Post-Consumer Waste Recycling and Optimal Production, E. Damanhuri, Ed., pp. 129-150, InTech, 2012, http://www intechopen.com/books/post-consumer-waste-recycling-andoptimal-roduction/electronics-waste-recycling-of-mobilephones.

[31] El-Kretsen, 2014, http://www.el-kretsen.se.

[32] H. M. Lee and E. Sundin, "The Swedish WEEE systemchallenges and recommendations," in Proceedings of the IEEE International Symposium on Sustainable Systems and Technology (ISSST '12), pp. 16-18, Boston, Mass, USA, May 2012.

[33] U. Lehtinen, K. Poikela, J. Ylä-Mella, and E. Pongrácz, "Examining the WEEE recovery supply chain: empirical evidence from Sweden and Finland," in Proceedings of the 21st Annual NOFOMA Conference, Jönköping, Sweden, June 2009.

[34] A. Bernstad, J. la Cour Jansen, and H. Aspegren, "Property-close source separation of hazardous waste and waste electrical and electronic equipment-a Swedish case study," Waste Management, vol. 31, no. 3, pp. 536-543, 2011.

[35] A. Bernstad, J. La Cour Jansen, and H. Aspegren, "Local strategies for efficient management of solid household wastethe full-scale Augustenborg experiment," Waste Management \& Research, vol. 30, no. 2, pp. 200-212, 2012.

[36] S. Miafodzyeva, N. Brandt, and M. Andersson, "Recycling behaviour of householders living in multicultural urban area: a case study of Järva, Stockholm, Sweden," Waste Management and Research, vol. 31, no. 5, pp. 447-457, 2013.

[37] E. Román, "WEEE management in Europe: learning from best practice," in Waste Electric and Electronic Equipment (WEEE) Handbook, V. Goodship and A. Stevels, Eds., pp. 493-525, Woodhead Publishing, 2012.

[38] EE-registeret, 2014, http://www.eeregisteret.no.

[39] E. Román, J. Ylä-Mella, E. Pongrácz, W. D. Solvang, and R. Keiski, "WEEE management system: cases in Norway and Finland," in Proceedings of the Electronics Goes Green Conference, Berlin, Germany, September 2008.

[40] State of the Environment Norway, "Waste electrical and electronic equipment," 2014, http://www.environment.no/Topics/ Waste/Waste-electrical-and-electronic-equipment/.
[41] Ministry of Justice in Finland, Finlex Data Bank, 2014, http:// finlex.fi/en/.

[42] Government Offices of Sweden, "Environment, energy and planning," Swedish Code of Statutes, 2014, http://www.government.se/sb/d/3288/a/19572.

[43] Norwegian Environment Agency, "Regulations relating to the recycling of waste (waste regulations)," 2014, http://www.miljodirektoratet.no/no/Regelverk/Forskrifter/Regulations-relatingto-the-recycling-of-waste-Waste-Regulations.

[44] Ministry of the Environment in Finland, "Economic influence and costs of Waste management in Finland," Reports of Ministry of the Environment, 2014 (Finnish), http://www.ym.fi/fiFI/Ajankohtaista/Julkaisut/Raportteja_RA.

[45] Finland's Environmental Administration, "Producer responsibility in waste management,” 2014 (Finnish), http://www.ymparisto.fi/fi-FI/Kulutus_ja_tuotanto/Jatteet_ja_jatehuolto/Tuottajavastuu.

[46] Eurostat, "Environmental data centre on waste-Waste Electrical and Electronic Equipment (WEEE)," 2014, http://epp.eurostat.ec.europa.eu/portal/page/portal/waste/key_waste_streams/ waste_electrical_electronic_equipment_weee.

[47] Statistics Finland, "Official statistics in Finland 2011," 2012, http://www.stat.fi/til/jate/2011/jate_2011_2012-11-20_fi.pdf.

[48] Statistics Finland, "Official statistics in Finland 2012," 2013, http://www.stat.fi/til/jate/2012/jate_2012_2013-11-26_fi.pdf.

[49] EÅF (Elektronikåtervinningsföreningen i Sverige), "WEEE Statistics," 2014, http://elektronikatervinning.com/en/information/weee-statistics/.

[50] Eurostat, "Waste statistics-electrical and electronic equipment," 2014, http://epp.eurostat.ec.europa.eu/statistics_explained/index.php/Waste_statistics_-_electrical_and_electronic_ equipment.

[51] J. Huisman, M. van der Maesen, R. J. J. Eijsbouts, F. Wang, C. P. Baldé, and C. A. Wielenga, The Dutch WEEE Flows, United Nations University, ISP-SCYCLE, Bonn, Germany, 2012.

[52] R. Peagam, K. Mcintyre, L. Basson, and C. France, "Businessto-business information technology user practices at the end of life in the United Kingdom, Germany, and France," Journal of Industrial Ecology, vol. 17, no. 2, pp. 224-237, 2013. 

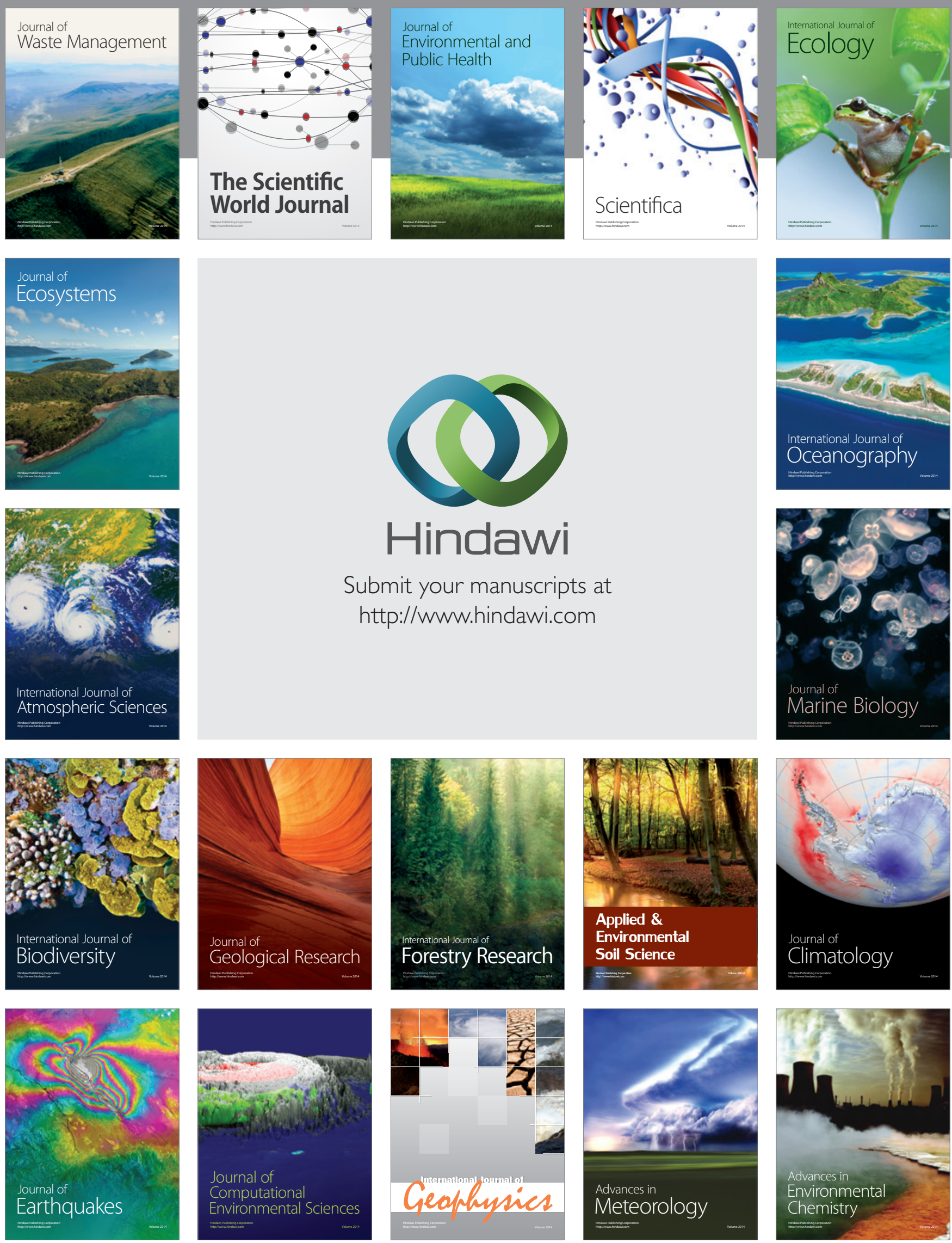